\title{
The institutional and cultural framing of the educational stratification in fertility. A review of the role of labor market institutions and attitudinal orientations
}

\author{
Daniela Bellani \\ University of Florence, Department of Statistics, Computer Science, Applications "G. Parenti"Viale Morgagni 59, 50134, Firenze, Italy
}

\section{A R T I C L E I N F O}

\section{Keywords:}

Educational gradient

Fertility

Institutions

Attitudes

\begin{abstract}
A B S T R A C T
The aim of this article is to overcome the incomplete explanation of previous research findings on the societal determinants of the educational fertility differentials in Europe. Our analysis draws on two overlooked factors, the role of labour market setting and the diffusion of new values. Combining ESS, EVS and WVS data for 2004-2009 with contextual indicators on labour market setting and cultural orientations, our multilevel analysis shows that labour market conditions in terms of share of part time jobs, dimension of public sector employment and strictness of EPL do not systematically modify the gradient of fertility by parities. But instead, we observe a clear moderator effect of attitudinal orientations. Results show that in societies where postmodernism is widespread, both high and low educated women are less likely to have children. A high diffusion of gender egalitarianism is associated with a reduction of the gradient through an increase of the likelihood of having a child especially for higher educated women. This article concludes by highlighting some responses to societal polarization of fertility related to both structural and cultural factors and indicates avenues for future research on the social stratification of fertility.
\end{abstract}

\section{Background and objectives}

Over the last few decades, developed countries have experienced an extraordinary transformation in their demographic structure. Such phenomena are (partly) the result of a steady decline in fertility due to the postponement of entry into parenthood, the rise of childlessness and the reduction of the total number of children in families (Freijka \& Sobotka, 2008). The upsurge of women's participation in higher education has been identified as a major driving force behind these transformations (Billari \& Kohler, 2004). Sociological and demographic research (e.g. Blossfeld \& Huinink, 1991), in fact, typically has found that female education is negatively associated with fertility. Nonetheless, recent empirical evidence stresses that the negative correlation between female educational attainment and family size is weakening and even turning positive (e.g. Kravdal \& Rindfuss, 2008). This reversal has occurred in some countries such as Sweden (Andersson et al., 2008), France (Davie \& Mazuy, 2010) and the United States (Hazan \& Zoabi, 2015), but not in others, such as Italy (Impicciatore and Dalla Zuanna, 2017) and Spain (Wood, Neels, \& Kil, 2014). With this backdrop, the puzzle is why the educational gradient in fertility varies across regions.

The understanding of contextual factors reinforcing or weakening the female educational gradient of fertility would greatly help to solve this puzzle, but also to predict fertility trends and future social inequality. In fact, the identification of the patterns of the relationship between women's education and childbearing is crucial since it can have profound consequences on the welfare of a society. First of all, in an historic moment marked by a rapid expansion of tertiary education, the fertility behaviour of highly educated women increasingly contributes to determining the national level of fertility (Bavel \& RóżańskaPutek, 2010). Second, since educational attainment is an accurate reflection of the opportunities and resources available to individuals, a marked (smoothed) educational gradient of fertility can lead to reinforce (weaken) issues of social stratification for the succeeding generation (Kravdal \& Rindfuss, 2008).

Social scientists have examined several institutional aspects to grasp insights into the cross-country variation in the educational fertility differentials of women. Since education mirrors specific attitudes, opportunity and constraints, the idea is that the effects of institutional factors on fertility quantum are likely to be heterogeneous by women's level of education.

A large number of scholars have focused their analyses on family policies as instruments for reducing work-family conflicts (Janus, 2013; Stier, Lewin-Epstein, \& Braun, 2012), showing that childcare provision (Gustafsson \& Stafford, 1994), financial transfers (Gauthier \& Hatzius, 1997) and parental leave entitlements (Ray, Gornick, \& Schmitt, 2010) play a crucial role in decreasing the steepness of the educational

E-mail address: Daniela.bellani@unifi.it. 
gradient of fertility (Thévenon, 2011). However, some researchers have called into question the validity of these conclusions. The argument that family policies are crucial for a reduction of the educational gradient in fertility does not succeed in offering a persuasive explanation for the weakening of the educational gap experienced by countries offering minimal state support to families (i.e. the United States; Vos, 2009).

To date, few comparative studies have comprehensively explored whether other institutional factors are more salient in this regard (Klesment, Puur, Rahnu, \& Sakkeus, 2014). Even if scholars (e.g. Adsera, 2011a, 2011b), have shown that fertility rates are associated with labour market settings, it is not clear whether this association is multidimensional ways likely to lead to heterogeneity in fertility outcomes across social strata. Moreover, the analysis of the influence on the gradient has overlooked the role of other macro factors such as cultural orientations - despite the recognition of some scholars (e.g. Sullivan, Billari, \& Altintas, 2014) that socially-shared values are essential in explaining the association between education and reproductive choices.

The main novelty of this study lies in the effort to comprehend what kind of factors (labour market factors, normative climate, etc.) exacerbate or flatten the negative association between female education and completed fertility. In particular, this article seeks to make both a theoretical and empirical contribution. First, we will critically discuss the most relevant theoretical models that attempt to explain the cross-country variation of the educational gradient in fertility. Existing theories offer competing explanations. On one side, the New Home Economics framework conceptualizes institutional factors as the most relevant determinants of such variation. From another standpoint, proponents of the post-modernist variant of the Second Demographic Transition (SDT) theory and the Multiple Equilibrium model argue that the crux of the matter lies in cultural heritage. More specifically, the post-modernist variant of the SDT theory predicts that it is the degree of diffusion of values nurturing secularization and individualism that shapes the gradient (van de Kaa, 2001). The Multiple Equilibrium model, instead, assumes that the most powerful predictor of the educational gap is the level of adherence to gender-neutral attitudes (Esping-Andersen \& Billari, 2015). One limitation of these frameworks is that they offer univocal expectations about the role of contextual factors on parity transitions. Recent studies (e.g. Billingsley \& Ferrarini, 2014; Impicciatore \& Dalla Zuanna, 2017) have emphasized, however, that disentangling the complex link between education and fertility involves identifying the influence of contextual variables based on family birth order in families. In order to address this gap in the literature, we will try to enrich the predictions of the three theoretical frameworks. Specifically, we will consider the role of interactions between macro characteristics and women's educational level for each parity.

Second, we will empirically analyse the relationship between educational attainment and completed fertility, applying a sort of conditional-sequential perspective to fertility decision-making (e.g. Nitsche, Matysiak, Van Bavel, \& Vignoli, 2018) that helps to estimate how societal factors are associated to female educational gradient by specific parity.

Our cross-sectional study, employing data from the European Social Survey Round 2 and 3 for 2004 and for 2006, the European Value Study for 2008-9 and the World Value Survey for 2005/2009, includes several countries of the European Union. Doing that, we are able to exploit a relevant contextual heterogeneity in terms of family dynamics, employment regulation and cultural heritage. The focus was on women who, during the selected period, were (almost) at the end of their reproductive career.

The remainder of this article is structured as follows: in Section 2 we provide a review of the existing literature about the main mechanisms underlying educational differences in fertility decisions. In Sections 3 and 4 we present and discuss our empirical results. We conclude in Section 5.

\section{Educational gradient, institutions and values: theoretical background and hypotheses}

Our analysis is grounded in theoretical models that provide insights into the contextual factors that influence the association between women's education and fertility choices. As we will explain in detail below, while New Home Economics theory emphasizes the role of institutions (Becker, 1981), the Second Demographic Transition theory (Lesthaeghe, 1995; van de Kaa, 2001) and the Multiple Equilibrium framework (Esping-Andersen \& Billari, 2015) draw attention to value change.

\subsection{Educational gradient and structural factors: the economic perspective of the role of labour market institutions}

The New Home Economics paradigm (Becker, 1981) posits fertility to be lower among societal groups with higher opportunity costs of childcare labour. Under this framework, the opportunity costs of motherhood are generally expected to be higher for better-educated women. A recent extension of the argument assumes that effective costs and benefits of childbearing are influenced by the level of opportunities for combining motherhood and employment (e.g. Blossfeld \& Huinink, 1991). Where social and economic institutions ease the combination of paid work with family duties, the income effect is likely to dominate the substitution effect, entailing higher 'pro-family' orientations of better educated women (e.g. Del Boca, Pasqua, \& Pronzato, 2006). This explains the cross-national variation of the educational gradient of fertility. The theoretical model is not explicit, however, about the impact of the institutional context on the educational gradient across parities. We do think this is an overlooked aspect in the literature.

Previous studies on the link between regulatory aspects of the labour market and the educational gradient of fertility (e.g. Begall \& Mills, 2011) have mainly focused on the level of employment opportunities and the degree of working-time flexibility - leaving other crucial factors only partly addressed. In this paper, we focus on three key elements of labour market regulation: the availability of part-time jobs, the size of public sector employment and the degree of rigidity of the employment protection legislation (EPL).

We are aware that the study of higher order parities may be subject to self-selection issues. In fact, women at different parities could vary across a range of unobserved characteristics, such as family preferences, that might potentially be associated with fertility choices (and thus number of children). Moreover, similar unobserved components may explain the educational level attained - women with stronger family preferences may typically invest less in education (Gottard, Mattei, \& Vignoli, 2015). This, in turn, can reduce the import of the macro-context as a factor in women's fertility decisions.

\subsubsection{Part-time work}

Several policymakers have considered part-time work as a strategy to promote the reconciliation between motherhood and female labour force participation (Schmitt, 2012). In particular, a stream of the socioeconomic literature has observed that part-time employment is a contractual form that enables mothers to successfully combine work and family duties while maintaining career opportunities and income (e.g. Begall \& Mills, 2011). According to this perspective, a higher prevalence of part-time opportunities lessens work-family conflicts because it reduces the general rigidity of working-time schedules, thus not 'forcing' women to decide between full-time employment and exclusion from the labour market (Gornick \& Heron, 2006). A number of studies suggest that part-time is especially crucial in improving work-family balance for those women who have at least one child, given they are more likely to experience the issue of 'time squeeze' related to family responsibilities (e.g. Begall \& Mills, 2011). And among mothers, the reduction of work-time is likely to be particularly favourable for those with higher education, since part-time schedule alleviates the issue of incompatibility between a higher work attachment and family duties (Gutiérrez-Domènech, 2008). Following this reasoning, one can expect that, in countries characterised by a high prevalence of part time work, 
the educational gradient of parity progression to second and third birth will be narrow.

Some scholars are sceptical about this argument (e.g. Del Boca et al., 2006). Their criticism concerns the assumption that it is the quantitative amount of opportunities for part-time work that enhances fertility. Instead, they argue, since part-time jobs are often associated with unfavourable working conditions (Kalleberg, 2000), the key factor is not the quantity itself but the quality of such position (in terms of protection, earnings and social benefits). Other studies (e.g. Walsh, 2007) also show that the promotion of part-time opportunities per se can represent a policy response to family-work conflicts that may not be attractive for more highly educated women. Part-time jobs or reducing working hours may offer limited prospects for career advancement. Moreover, eliciting employers' perception of lower work commitment can even produce a stigmatizing effect that may translate into career penalties (Walsh, 2007) - part-time work is often indicated as a 'female-typed' contractual form that leads to the so-called 'mommy track'. It follows that a high availability of part-time jobs can lead to promote a male breadwinner/female part-time career model (Dieckhoff, Gash, Mertens, \& Gordo, 2016; PfauEffinger, 2005) based on the idea that the wife, regardless of her income potential, is the second earner. Under such conditions, women with more education may be compelled to choose between having a part-time contract and motherhood on the one hand, and keeping valuable fulltime positions and remaining childless on the other (Del Boca et al., 2006). ${ }^{2}$ Thus, one could expect that higher educated women, in order to safeguard their educational investments, are more likely to opt for childlessness in those societies with a high availability of part-time jobs.

\subsubsection{Public sector employment}

Public sector jobs have usually been identified as an effective instrument for reducing the opportunity costs of motherhood (Adsera, 2004). The empirical evidence generally shows that women working in the public sector, compared with those in the private sector, benefit from higher levels of job stability, more protection against unemployment, considerable flexibility in time schedules and lower pressure when taking long parental leaves (e.g. Rønsen \& Skrede, 2010). Public sector work also goes hand-in-glove with classical female fields, such as teaching and healthcare, where supportive work-family culture is prevalent (Begall \& Mills, 2013). Thus, public sector employment has been considered a valid instrument to compensate for the costs of raising a child (GutiérrezDomènech, 2008). Socioeconomic literature has also shown that, in countries with larger public sectors, fertility rates are higher (Mandel \& Semyonov, 2006) and parity transitions are faster (Baizán, 2007). The size of public service sector is expected to have implications also for the link between education and fertility (Mandel \& Semyonov, 2006). Countries characterised by labour markets with a high availability of public sector work generally have a higher demand of white collar and service jobs. This indicates that, there, highly-educated women may have more opportunities to work in organisations that guarantee a balance between a (semi)professional career and childbearing (Martin Garcia \& Castro-Martin, 2013). Scholars have also demonstrated that an increase of occupations in the public sector provides highly educated women better opportunities for holding authority positions (e.g. Rosenfeld, Van Buren, \& Kalleberg, 1998). Given that state employment traditionally evolves in tandem with the provision of public services, an 'extended' public sector is also likely to offer a crucial support to career-oriented women in terms of homecare and childcare provision (Esping-Andersen,

\footnotetext{
${ }^{1}$ Only a few women have three or more children in the countries we consider: if they are selected to for high fertility preferences, they may tend to prefer a part-time instead than a full-time job and to have a third child.

${ }^{2}$ Part time contracts that guarantee job protection and suitable income may reduce the mismatch between career opportunities of higher educated women's and their family obligations. In our analysis, because of data limitations, we are not able to take into account the quality of part time jobs.
}

1999). All these wide-ranging effects are likely to strengthen women's power within the household and within a society-at-large (Bianchi, Casper, \& Peltola, 1999) and to create a supportive environment for work-family reconciliation - especially for women with college education (Stier \& Yaish, 2008). Thus, one could expect that the availability of public employment eases the transition to higher-order parities of bettereducated mothers. As in the case of parental leave benefits (Lalive \& Zweimüller, 2009), the improvement it provides to family-work balance is likely to be especially crucial for women with more education who already have a child. It is important to keep in mind that a selection effect could be at work here because such women could assign a higher value to the work-family balance associated with public employment.

There is no lack of critical voices regarding the beneficial role of public employment on fertility. The key argument of the so-called welfare state paradox is that labour markets with an extensive public sector, while offering better opportunities for combining work and family duties, also trigger female occupational segregation and gender wage gap (Charles \& Grusky, 2004; Gornick \& Jacobs, 1998). Given that public sector employment is generally characterised by wage compression and limited career prospects, in a context characterised by a substantial availability of such positions, highly educated women may be motivated to compete with men for more lucrative and qualified careers in the private sector (Mandel \& Semyonov, 2006). In such a context, however, private employers could be hesitant to hire or to promote mothers to the managerial level. In fact, they are willing to incur significant non-wage costs related to family-friendly employment practices, as may be legally supported (e.g. extremely generous maternity leave; Gangl \& Ziefle, 2009; Mandel \& Semyonov, 2006). This, in turn, could have a potentially adverse effect on labour market prospects and attainments of better-educated women (Evertsson et al., 2009) - that may face a starker either/or dilemma between a good job and motherhood. These consequences should allow the persistence of a negative gradient especially for higher order births, given the potential higher losses for better educated women in terms of career development associated with second and higher births.

\subsubsection{Strictness of EPL}

A brunch of the literature has predicted a negative association between the level of EPL and fertility rates (Brinton \& Lee, 2016; Rovny, 2011). The reasoning is that rigid EPL deters employers from offering highly regulated permanent positions (also during economic upturns), while it increases incentives to hire new entrants under temporary contracts (Bellani \& Bosio, 2019; Dolado, García-Serrano, \& Jimeno, 2002). Under these circumstances, it would be more difficult for young women (and men) to become fully integrated into safe and permanent work positions - usually held by the 'core workers', mainly male middle-aged employees (Boeri \& Garibaldi, 2007). As such, labour markets characterised by strict EPL are expected to increase the costs of setting up an independent household, thus resulting in a general depressive effect on fertility (Matysiak \& Węziak-Białowolska, 2016). ${ }^{3}$

Some scholars have documented that a certain level of EPL does not necessarily bring to an equal distribution of labour market risks across educational classes. Thus, educational groups may experience a heterogeneous impact on fertility even if they are subjected to the same labour market legislation (Wood et al., 2014). In strict EPL settings, both low and high-educated women (and men) typically enter into the labour market with temporary contracts; contractual instability,

\footnotetext{
${ }^{3}$ Scholars have also pointed out that in rigid labour markets young people are more likely to live longer with their parents as an insurance against labour market risks (Wolbers, 2007), provoking a postponement of partnering and parenthood (Fogli, 2004) that may lower the final number of children. Recent studies show that high EPL are generally associated with a segmentation of work-based social protection schemes that often denies the access to income protection programs and to family benefits for young couples (Palier and Martin, 2007). Even though distinct, these channels are mutually reinforcing and may hinder fertility aspirations and realizations (Vignoli et al., 2012).
} 
however, may represent only a temporary stage of the working career of better-educated workers (Mills \& Blossfeld, 2013). Thus, under these circumstances, highly educated women may just postpone their fertility plans. Instead, since less educated women are more likely to be entrapped in unstable jobs at the labour market periphery (Casquel \& Cunyat, 2005), motherhood is likely to be enduringly less affordable for low-educated women. One likewise can expect that, in contexts characterised by a rigid labour market regulation, the educational gradient in parity progressions is less negative, especially in the case of higher parities - given that, in this case, households have more individuals without income.

On the opposite, one strain of research hypothesises a positive association between the strictness of EPL and fertility realizations (e.g. Prifti \& Vuri, 2013). The argument here is the following: since rigid EPL makes it more difficult to fire workers from permanent jobs (Garibaldi \& Violante, 2005), it ultimately induces a general perception of income security. This, in turn, should positively affect the likelihood of having a (additional) child. Following the same reasoning, flexible employment legislation, characterised by marginal protection against unemployment, could preclude the realization of reproductive intentions (Kreyenfeld, 2009). Regarding the impact on educational groups, a flexible labour market regulation could widen educational differentials in childbearing, bringing a reduction of fertility among women with college education and a rise among the less educated. The reason is that, in labour markets characterised by flexible EPL, better educated women - being generally more career-oriented - are motivated to preserve their labour attachment so as to protect their progress to a permanent position. Under these circumstances, they could perceive raising a child as too costly (Liefbroer \& Corijn, 1999; Wood et al., 2014) thus opting for a smaller family size (limiting transitions to second and subsequent births). In low EPL settings, motherhood may be perceived by less educated women as an 'alternative career' and a strategic choice to structure an uncertain life course (Hurrelmann, 2003). This expectation refers especially to higher order births. Instead, in contexts with high EPL the educational gradient should disappear.

\subsection{Attitudes, gender values and family size: the cultural perspective}

The post-modernist variant of the SDT theory and the Multiple Equilibrium Model identify the educational gradient of fertility as a result of values and attitudes more than a product of 'institutional packages'that solely design specific structures of opportunities and constraints for parents (Saraceno \& Keck, 2008). Accordingly, whether the female educational gradient is negative or not depends on incentives or penalties determined by cultural factors associated with values and orientations (Granrose \& Kaplan, 1994; Liefbroer \& Corijn, 1999).

\subsubsection{Post-modernist variant of SDT}

The proponents of SDT theory claim that fertility behaviour is strongly related to the level of diffusion of post-modernist values and attitudes. The main proposition here is that individuals who embrace individualistic values perceive childbearing as an outcome of a planned decision (carefully taken), rather than a social obligation (van de Kaa, 2001). A decline in family commitment and the end of the 'child-king status', parallel to the diffusion of post-modernist values, are thus predicted.

Although adherents to the ideational theory have not explicitly elaborated a theoretical model on the impact of education on fertility behaviour, they implicitly assume that high education embodies a shift away from traditional values (Lesthaeghe, 2010). This is because levels of educational attainment reflect different learning processes of postmodernist values (Inglehart, 1997). ${ }^{4}$ Hence, highly educated women

\footnotetext{
${ }^{4}$ Demographic studies have acknowledged that values associated with post materialism and the SDT are strongly correlated with high education (e.g. Perelli-Harris et al 2010).
}

are identified as frontrunners of new attitudes such as autonomy and self-realisation (Lesthaeghe, 1995, van de Kaa, 2001). As such, they are expected to spearhead opposition to religious institutions and to protraditional family behaviour (Lesthaeghe, 2010). This, in turn, should result in a significative limitation of family size. ${ }^{5}$ In a second step all other educational classes are expected to embrace these family preferences and fertility behaviours. $^{6}$

Like Becker's framework, the basic formulation of the ideational theory lacks an explicit prediction about the cross-country variation of the educational gradient in fertility. However, it implicitly assumes that the international variation depends on the degree of diffusion of postmodernist attitudes at country level (Merz \& Liefbroer, 2012; Sobotka, 2008). Accordingly, the dampening effect of (female) high education on fertility is predicted to be heterogeneous across countries, stronger where the diffusion process of new norms is at early stage of diffusion, and weaker where post-modernism has gained a dominant status (Perelli-Harris \& Lyons-Amos, 2016; Sobotka, 2008). ${ }^{7}$ It is not clear, however, whether this effect is more salient for the first or higher parities. Nonetheless, one could expect that in countries with a low degree of diffusion of post-modernist values, highly educated women are less likely to progress to second and higher parities, compared to their lower educated counterpart. Instead, where the diffusion of post-modernism has reached a large proportion of the population, fertility patterns might be similar across educational groups.

\subsubsection{Multiple equilibrium}

A contrasting theoretical model, the Multiple Equilibrium framework, elaborated by Esping-Andersen and Billari (2015), affirms that, under some circumstances, female human capital is positively associated with fertility. One of the key factors distinguishing this theory to post-modernist variant of SDT is the importance attributed to what Esping-Andersen and Billari (2015) call the gender equity dividend. The authors theorise that fertility behaviour is crucially influenced by the degree to which a society adopts gender equitable attitudes; this, in turn, is expected to shape the educational divide in family size (EspingAndersen, 2009).

A principal tenet of the Multiple Equilibrium framework, that develops further the ideas of McDonald (2000a), 2000b, McDonald, 2006, about a U-shaped relationship between gender equity and fertility is that there are different stages of diffusion of gender-egalitarian values (and behaviours). These comprise traditional kinship, unstable equilibrium and gender egalitarian dominance (Esping-Andersen \& Billari, 2015). The three stages are characterised by a different educational gradient of fertility. The key lies in the positive association between gender egalitarian societies and gender-equal opportunities (Arpino, Esping-Andersen, \& Pessin, 2015). In traditional societies, characterised by a strict gender specialisation, and in gender-egalitarian societies, where the adoption of gender egalitarian practices has become universal, the gradient is expected to be null or even reversed (positive). This is because in countries dominated by male breadwinner-female housewife model, education should not act as a barrier to childbearing. In such societies, the dominance of gender specialisation and pro-family orientation attains normative hegemony across all the educational levels (Bellani, Esping-Andersen, \& Nedoluzhko, 2017). Therefore, the opportunity costs of childbearing are likely to be low across all educational groups. In parallel, in contexts characterised by high diffusion of gender-egalitarian norms, high- and low- educated women are expected to have similar fertility realizations because it is relatively more feasible for women to combine family duties and career - even for those

\footnotetext{
${ }^{5}$ The so called Maslowian drift (Zaidi and Morgan, 2017).

${ }^{6}$ Higher educated women are expected to be less susceptible to normative influence (Liefbroer and Billari, 2010).

${ }^{7}$ In other words, the higher the diffusion the lower the fertility gap between educational groups.
} 
facing steep opportunity costs of motherhood. The reason is that high diffusion of egalitarian norms related to the gender division of domestic work makes more compatible working and having children (Arpino et al., 2015; Goldscheider, Bernhardt, \& Lappegård, 2015). In contrast, where there is only a partial support for the 'gender-egalitarian' family model, women - especially those who are highly educated - should experience severe constraints in reconciling family and work because of the lack of male adaptation to new roles for women. Hence, for those societies where gender norms in the private sphere (but not in the public) remain resistant to change, Multiple Equilibrium theory predicts a negative gradient. ${ }^{8}$ This argument does not take into consideration, however, that the moderator role of gender egalitarianism may vary according to specific parity progression. Gender egalitarianism should play a crucial role, especially in the case of higher-order births, since the family-career balance is generally more difficult to achieve after the first birth (Luppi, 2016; Matysiak, Mencarini, \& Vignoli, 2016). Thus, one could predict that the educational gradient becomes especially marked in the progression toward higher-order births in those countries that fit the unstable equilibrium framework.

\section{Data, variables and methodology}

We combined three different datasets, European Social Survey (ESS) 2004/2005 (Round 2) and 2006/7 (Round 3), World Value Survey (WVS) 2005/2009 and European Value Study (EVS) 2008/9. Since all the three surveys are characterised by a set of comparable variables across all countries, we pool the three datasets. ${ }^{9}$ Doing so, we obtain larger national samples that ease cross-country comparisons between sub-groups broken down by individual characteristics such as education. Although ESS, WVS and EVS data are cross-sectional, the selected waves collect information about women's completed fertility - this information is not available in more recent rounds of the surveys. ${ }^{10}$

We employed all the European countries when it was found possible to gather information on crucial independent variables at micro-level and to collect contextual variables (at country-cohort level). For these reasons, we select a sample of 24 European countries. Since we are interested in completed fertility indicators, we restrict our analyses to the sub-sample of women aged 42-57 born between 1950 and 1963, whose fertility histories are broadly completed. ${ }^{11}$ We split the sample in two cohorts, women born between 1950 and 1956 and women born between 1957 and 1963 since the two cohorts of women were embedded in (partly) different socio-economic contexts during their life course. ${ }^{12}$ Indeed, the contextual features that we take into consideration do not only vary by country but also by cohort; hence our approach exploits both variations across countries and across cohorts. Doing so, we consider two levels since individuals are nested in country-cohort combinations (two level-units). As a result, we have 45 country-cohort

\footnotetext{
${ }^{8}$ Bellani et al. (2017) show that this is the case for the likelihood of being in a marriage or cohabitation.

${ }^{9}$ Previous studies have already used these data sources in order to study parity-specific fertility or fertility quantum (Huijts et al., 2011, Kalwij, 2010). However, a limitation is that the number of children declared should include not only respondents' biological children but also step, adopted, foster or partner's children.

${ }^{10}$ We are aware that the period considered includes 2008 and 2009, years when the economic crisis started. However, its effect in the 'real economy' became evident since 2009-2010. Since we consider in our analysis only completed fertility, we are confident that our results are not biased.

${ }^{11}$ We decide to select this age interval because we want to study the association between completed fertility and some contextual measures that are available only for this specific segment of the population. Moreover we want to avoid inaccuracy in the information due to memory lapses on the total number of children. As robustness check, we select also women aged 45-60. Results do not change (analysis upon request).

${ }^{12}$ For Estonia, Bulgaria and Slovenia data are available for one cohort, only.
}

units. A list of these units is provided in the Appendix (Table A1). ${ }^{13}$

We conduct our analysis comparing women at different parities the samples pool individuals at higher parities to maximize the sample.

\subsection{Individual variables}

We focus on woman's parity, defined as the number of children a woman has ever borne. Similarly to previous studies (Barakat \& Durham, 2013; Nisén, Martikainen, Kaprio, \& Silventoinen, 2013; Nisén, Martikainen, Silventoinen, \& Myrskylä, 2014), we consider three dependent variables: parity 1 or higher versus childlessness (having at least one child or not having children), parity 2 or higher versus parity 1 (having more than one child or having one) and parity 3 or higher versus parity 2 (having more than two children or having two children). We label the first dummy variable as $\mathrm{P} 1+$, the second as P2+ and the third as $\mathrm{P} 3+$. In our study these dummies were constructed using the variable total "number of children" collected in all the datasets, with the only exception of ESS Round 2. In this case we derived the variable adding together the number of children that moved out of the respondent's house with the number of children that were living in the respondent's house. ${ }^{14}$

We use the highest educational level attained by women at the time of the interview as explanatory variable. We reduced the detailed information existing in the data regarding the respondent's level of education to three categories, a) lower secondary education or less, that represents the level 0-2 of the International Standard Classification of Education 1997 (ISCED from now on), b) upper secondary non-tertiary education (ISCED 3-4) and c) tertiary education (ISCED 5-6) - as standard practice for European studies on educational gradient in fertility choices. We label the first category as low education, the second as medium education and the third as high education. ${ }^{15}$

We include, at the individual level, three control variables, the age of the respondent (to adjust for the length of time a woman was at risk of having an additional child), a categorical variable to identify the surveys, and a dummy for the respondent's birth cohort. ${ }^{16}$

Descriptive statistics about individual-level variables are reported in Table 1.

\subsection{Macro-level variables}

We consider key-factors to identify the extent to which labour market regulation and the attitudinal orientations are associated with fertility realizations. We construct contextual variables at country level that refer to the period 1989-96 for the respondents of the first cohort and 1997-2005 for those of the second cohort (country-cohort

\footnotetext{
${ }^{13}$ We replicate the same analysis with three levels in the multi-level analysis, individuals, country-periods and country. Results are pretty similar (analysis upon request).

${ }^{14}$ ESS Round 3, WVS of 2005-2009 and EVS of 2008-9 contains a question about the total number of children of the respondent, while for the ESS Round 2 the variable on the total number of children has been reconstructed. For ESS Round 2 we add the number of children of the respondent that do not live in the household to the number of children that live in the household. To check whether there are significant differences between the two waves of ESS within countries we implement a statistical test ( $\mathrm{T}$ test) to assess whether the means of the number of children of the two datasets by countries are statistically different from each other. This is not the case, with the exception of France and Hungary for the first cohort considered and Austria, Poland and Slovakia for the second cohort. As "Robustness checks" we provide test excluding these countries from the ESS Round 2.

${ }^{15}$ An important caveat is that this variable captures the situation at the time of the interview; however, it is possible that a share of the completed fertility was realized while she was in a different educational group.

${ }^{16}$ One limitation of our model is that we are not able to control for the marriage history of the individual. Another limitation is the lack of data on children's ages.
} 
Table 1

Description of the individual-level variables, pooled dataset.

\begin{tabular}{|c|c|c|c|c|c|c|c|c|c|c|c|c|}
\hline & \multicolumn{4}{|c|}{ P1 + vs 0 child } & \multicolumn{4}{|c|}{ P2+ vs 1 child } & \multicolumn{4}{|c|}{ P $3+$ vs 2 children } \\
\hline & Mean & SD & Min & Max & Mean & SD & Min & Max & Mean & SD & Min & $\operatorname{Max}$ \\
\hline \multicolumn{13}{|l|}{ Parities } \\
\hline Parity & $87.24 \%$ & & & & $79.14 \%$ & & & & $41.37 \%$ & & & \\
\hline Lower parity & $12.76 \%$ & & & & $20.86 \%$ & & & & $58.63 \%$ & & & \\
\hline Age & 49.23 & 4.24 & 42 & 57 & 49.25 & 4.25 & 42 & 57 & 49.26 & 4.25 & 42 & 57 \\
\hline \multicolumn{13}{|l|}{ Education } \\
\hline Low & $31.26 \%$ & & & & $32.30 \%$ & & & & $33.16 \%$ & & & \\
\hline Medium & $43.09 \%$ & & & & $43.07 \%$ & & & & $42.46 \%$ & & & \\
\hline High & $25.65 \%$ & & & & $24.63 \%$ & & & & $24.37 \%$ & & & \\
\hline \multicolumn{13}{|l|}{ Dataset } \\
\hline ESS & $62.05 \%$ & & & & $61.35 \%$ & & & & $60.90 \%$ & & & \\
\hline EVS & $28.61 \%$ & & & & $29.15 \%$ & & & & $29.50 \%$ & & & \\
\hline WVS & $9.35 \%$ & & & & $9.50 \%$ & & & & $9.60 \%$ & & & \\
\hline \multicolumn{13}{|l|}{ Birth-cohort } \\
\hline $1950-56$ & $44.77 \%$ & & & & $44.63 \%$ & & & & $44.82 \%$ & & & \\
\hline $1957-63$ & $55.23 \%$ & & & & $55.37 \%$ & & & & $55.18 \%$ & & & \\
\hline $\mathrm{N}$ & 15524 & & & & 13587 & & & & 10753 & & & \\
\hline
\end{tabular}

Table 2

Macro-level determinants of parities: definition and sources.

\begin{tabular}{|c|c|c|c|}
\hline Macro level determinant & Indicator & Measurement & Source \\
\hline $\begin{array}{l}\text { Access to part time employment for } \\
\text { women }\end{array}$ & $\begin{array}{l}\text { Proportion of women working part- } \\
\text { time }\end{array}$ & $\begin{array}{l}\text { Part time employment as percentage of the total employment of women aged } \\
25-54 \text {. }\end{array}$ & OECD \\
\hline $\begin{array}{l}\text { Access to public sector employment } \\
\text { for women }\end{array}$ & $\begin{array}{l}\text { Proportion of women in public } \\
\text { employment }\end{array}$ & Female public employment as a percentage of all employed women. & UNECE \\
\hline Flexibility of labour market & $\begin{array}{l}\text { Rigidity of employment protection } \\
\text { legislation }\end{array}$ & Index of EPL on regular workers. & OECD \\
\hline Post-modernist attitudes & Diffusion of "non-traditional" attitudes & $\%$ of respondents aged $15-55$ that declare that religion is not important in life. & EVS and WVS. \\
\hline $\begin{array}{l}\text { Gender egalitarian attitudes in the } \\
\text { labour market }\end{array}$ & Diffusion of gender egalitarian attitudes & $\begin{array}{l}\% \text { of respondents aged } 15-55 \text { that disagree or strongly disagree with the } \\
\text { statement "When job are scarce men should have more right to a job than } \\
\text { women". }\end{array}$ & EVS and WVS \\
\hline HDI & Human Development Index & $\begin{array}{l}\text { Summary measure of average achievement in key dimensions of human } \\
\text { development: a long and healthy life, being knowledgeable and have a decent } \\
\text { standard of living. }\end{array}$ & $\begin{array}{l}\text { United } \\
\text { Nations }\end{array}$ \\
\hline Weighted maternal leave weeks & $\begin{array}{l}\text { Sum of weeks of maternity leave } \\
\text { weighted }\end{array}$ & Number of weeks of maternal leave weighted by level of cash benefits. & ILO \\
\hline Gross enrolment rate in pre-primary & $\begin{array}{l}\text { Gross enrolment rate in pre-primary } \\
\text { school }\end{array}$ & $\begin{array}{l}\% \text { of children enrolled in pre-primary school over the total of children of the } \\
\text { same age. Note that this indicator can exceed } 100 \% \text { due to the inclusion of } \\
\text { over-aged and under-aged pupils/students, therefore causing a discrepancy } \\
\text { between the numerator and denominator of this index. }\end{array}$ & UNESCO \\
\hline Total family benefits & $\begin{array}{l}\text { Public expenditure for family benefits } \\
\text { as \% of GDP }\end{array}$ & $\%$ of GDP for family benefits. & OECD \\
\hline Female participation rate & $\begin{array}{l}\text { Rate of female participation in the } \\
\text { labour market }\end{array}$ & $\%$ of women that are active in the labour market (employed and unemployed). & ILO \\
\hline $\begin{array}{l}\text { Life-long singlehood rate for } \\
\text { women }\end{array}$ & $\begin{array}{l}\text { Rate of women that have never married } \\
\text { or cohabiting until the age of } 40\end{array}$ & $\%$ of life long single women (birth cohorts $1950-56$ and $1957-1963$ ) & ESS and EVS \\
\hline
\end{tabular}

variables). ${ }^{17}$ This is because we assign values of the macro-indicators that can capture contextual conditions to women during their 30 's, a life stage when key decisions about fertility choices are done - such as taking the decision to forgo children or whether to "catch-up" the postponement of conception. ${ }^{18}$ Detailed definition and description of macro variables are reported in Tables 2 and 3, respectively. Note that if we did not allow the contextual indicators to vary between country and cohort, we would not capture the variation of the contextual indicators across cohorts, thus limiting our ability to identify contextual

\footnotetext{
${ }^{17}$ We are compelled to estimate with a cohort dummy rather than a continuous age specification since for many countries we do not have more than one observation by cohort on (one or more) variables at aggregate level.

${ }^{18}$ We do not have enough information on main relevant variables when the selected women were in their 20 s.
}

influence.

In order to depict the configuration of the labour market regulation at country-level, we include three indicators.

The first one is the availability of female part-time employment calculated as the share of women working part-time out of the total number of female working population - retrieved by the OECD Statistical Database. It assumes small values (from about $2 \%-10 \%$ ) in Eastern European countries to more than $50 \%$ in the Netherlands. In some cases, such as Denmark, Norway and Sweden, we observe a considerable variation between cohorts (Table 3 ).

The second indicator is the prevalence of women in public employment operationalized as the percentage of women employed in the public sector over all the employed women - retrieved by the UNECE Statistical database. As we can observe from Table 3, there is a relevant country variation - from 10 to $12 \%$ in Turkey to more than $60 \%$ in 
Table 3

Descriptive statistics of macro-level variables, \%, and rank order of countries-cohort by macro-level variable.

\begin{tabular}{|c|c|c|c|c|c|c|c|c|c|c|}
\hline & \multicolumn{2}{|c|}{ Part time prevalence } & \multicolumn{2}{|c|}{ Public sector prevalence } & \multicolumn{2}{|c|}{ Strictness of EPL on regular workers } & \multicolumn{2}{|c|}{ Post modernism indicator } & \multicolumn{2}{|c|}{ Gender egalitarianism approval } \\
\hline & First cohort & Second cohort & First cohort & Second cohort & First cohort & Second cohort & First cohort & Second cohort & First cohort & Second cohort \\
\hline AT & $24.40(26)$ & $28.68(31)$ & . & $18.00(6)$ & $2.75(34)$ & $2.62(29)$ & $46.81(10)$ & $51.60(14)$ & $49.21(7)$ & $61.97(15)$ \\
\hline $\mathrm{BE}$ & 34.61 (35) & $35.73(38)$ & 24.15 (13) & 30.47 (17) & $1.85(8)$ & $1.87(9)$ & 59.94 (18) & $58.83(17)$ & $57.47(10)$ & $77.41(32)$ \\
\hline $\mathrm{CH}$ & $46.80(43)$ & $46.51(42)$ & $18.10(7)$ & 20.73(9) & $1.60(5)$ & $1.60(6)$ & 60.86 (19) & . & $60.83(14)$ & . \\
\hline $\mathrm{CZ}$ & $3.56(4)$ & $3.54(2)$ & $57.15(36)$ & $29.80(16)$ & $3.31(42)$ & $3.31(43)$ & $81.90(42)$ & $85.24(44)$ & $43.66(5)$ & $63.71(18)$ \\
\hline $\mathrm{DE}$ & $31.24(33)$ & 36.53 (39) & . & $16.20(5)$ & $2.63(30)$ & $2.68(32)$ & $74.26(36)$ & 78.11 (39) & $65.69(20)$ & 65.47 (19) \\
\hline DK & $21.14(22)$ & 15.80 (19) & . & $48.62(34)$ & $2.16(14)$ & $2.13(13)$ & 75.90 (37) & $78.62(40)$ & $93.37(42)$ & $93.01(40)$ \\
\hline $\mathrm{EE}$ & . & $6.45(7)$ & $61.40(37)$ & $34.95(24)$ & 2.90 (39) & $2.74(33)$ & $80.50(41)$ & $84.45(43)$ & $52.35(9)$ & $76.77(31)$ \\
\hline ES & 12.59 (15) & $16.06(20)$ & 21.35 (10) & $20.05(8)$ & $3.15(41)$ & $2.36(22)$ & 54.29 (18) & $63.16(24)$ & $67.72(22)$ & $71.38(25)$ \\
\hline FI & $7.83(9)$ & $8.96(11)$ & 40.05 (29) & $4.03(28)$ & $2.55(28)$ & 1.99 (10) & $63.28(26)$ & $64.36(28)$ & 76.74 (30) & 88.18 (37) \\
\hline FR & $22.79(23)$ & $23.33(24)$ & $31.60(20)$ & 30.50 (18) & $2.34(20)$ & $2.38(24)$ & $64.18(27)$ & $68.71(32)$ & $63.22(17)$ & 72.26 (27) \\
\hline GB & $40.76(41)$ & $36.78(40)$ & 31.55 (19) & $31.80(21)$ & $1.10(1)$ & $1.21(2)$ & $62.12(23)$ & 64.68 (29) & $73.10(28)$ & $84.18(35)$ \\
\hline GR & $13.86(18)$ & $12.43(14)$ & $22.35(11)$ & $23.68(12)$ & $2.80(36)$ & 2.80 (37) & . & $33.40(8)$ & . & 74.82 (29) \\
\hline $\mathrm{HU}$ & . & $3.84(6)$ & . & 36.55 (25) & $2.00(11)$ & $2.00(12)$ & $63.19(25)$ & $67.76(31)$ & 59.28 & 60.61 (13) \\
\hline IE & 26.68 (27) & $32.21(34)$ & . & 29.60 (15) & $1.44(3)$ & $1.44(4)$ & $21.02(5)$ & $31.78(6)$ & $66.95(21)$ & $82.90(34)$ \\
\hline IS & 35.33 (37) & 27.19 (28) & . & $45.60(31)$ & . & $1.73(7)$ & $50.62(13)$ & $50.13(12)$ & $93.11(41)$ & $95.38(44)$ \\
\hline $\mathrm{LU}$ & 27.57 (29) & $31.16(32)$ & $9.30(1)$ & $13.42(4)$ & . & $2.25(16)$ & . & $61.14(20)$ & . & $70.10(24)$ \\
\hline NL & $55.11(44)$ & $56.33(45)$ & . & $33.10(22)$ & $2.96(40)$ & $2.87(38)$ & $62.00(22)$ & 70.04 (33) & 77.91 (33) & $89.08(38)$ \\
\hline NO & $34.81(36)$ & $28.64(30)$ & . & $47.45(32)$ & $2.33(18)$ & 2.33 (19) & $67.00(30)$ & . & $85.16(36)$ & . \\
\hline PL & 11.30 (13) & $13.11(16)$ & 49.50 (35) & 38.62 (27) & $2.23(15)$ & $2.23(16)$ & $12.93(3)$ & $19.16(4)$ & $35.71(2)$ & $49.76(8)$ \\
\hline PT & 13.84 (17) & $8.56(10)$ & . & 25.60 (14) & $4.69(46)$ & $4.55(45)$ & $45.76(9)$ & $31.93(7)$ & 59.95 (12) & $68.00(23)$ \\
\hline SE & $23.51(25)$ & $17.45(21)$ & . & $47.80(33)$ & 2.79 (35) & $2.35(21)$ & 76.15 (38) & $71.00(35)$ & 92.79 (39) & $95.01(43)$ \\
\hline SI & . & $3.68(5)$ & $33.80(23)$ & $37.67(26)$ & $3.40(44)$ & $2.65(31)$ & $61.15(21)$ & 70.17 (34) & $63.11(16)$ & $71.48(26)$ \\
\hline SK & 3.55 (3) & $2.71(1)$ & $66.45(38)$ & $40.43(30)$ & 2.47 (27) & $2.40(26)$ & $57.16(16)$ & $48.42(11)$ & $39.07(3)$ & $47.92(6)$ \\
\hline TR & $11.03(12)$ & $6.64(8)$ & $9.90(2)$ & $11.97(3)$ & 2.39 (25) & 2.37 (23) & $12.32(2)$ & 8.65 (1) & 39.95 (4) & $33.46(1)$ \\
\hline
\end{tabular}

Note: first birth cohort corresponds to 1950-1956, second birth cohort corresponds to.1957-1963.
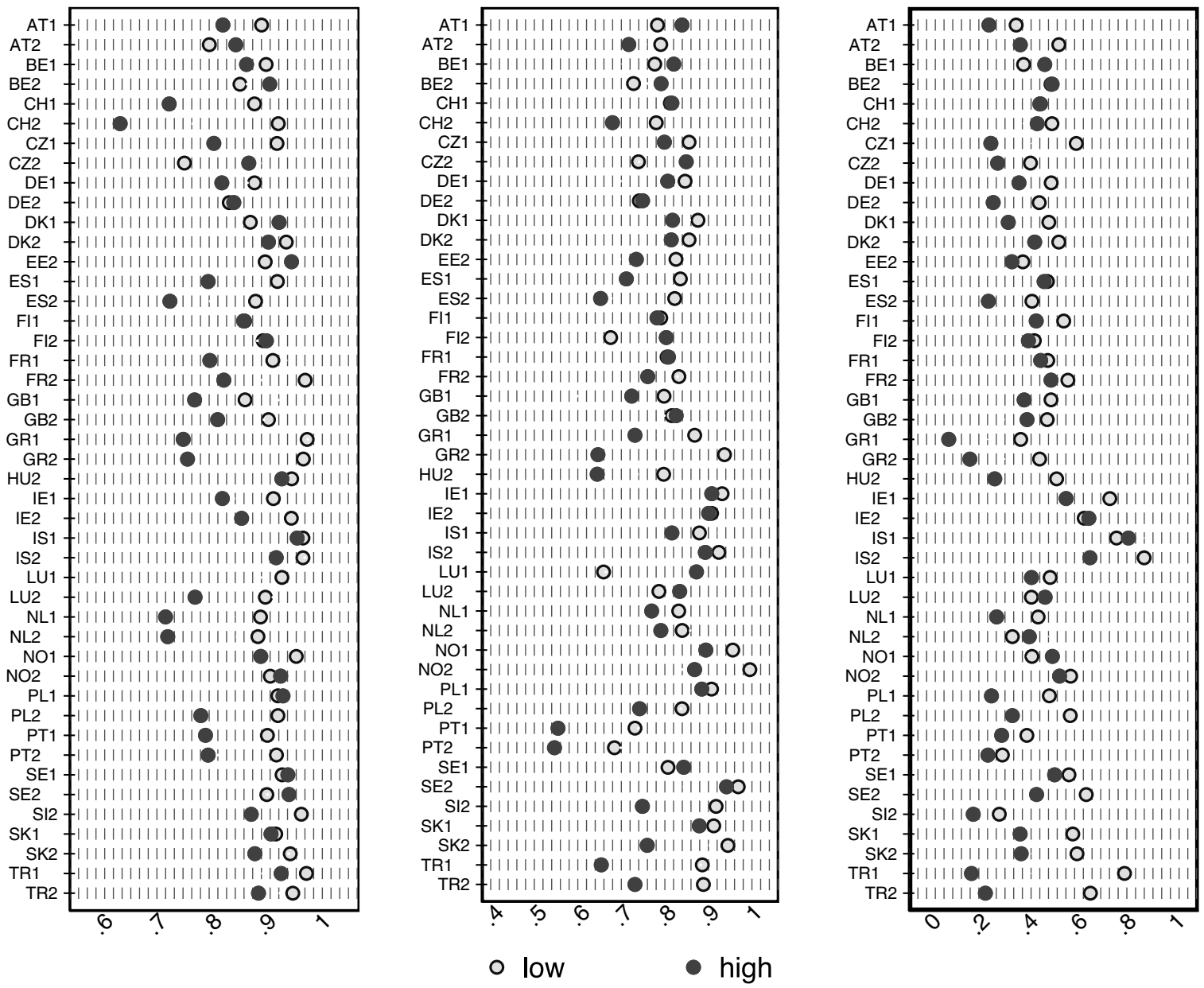

Fig. 1. Predicted probabilities P1 +, P2 + and P3+, by educational level and country-cohort. 

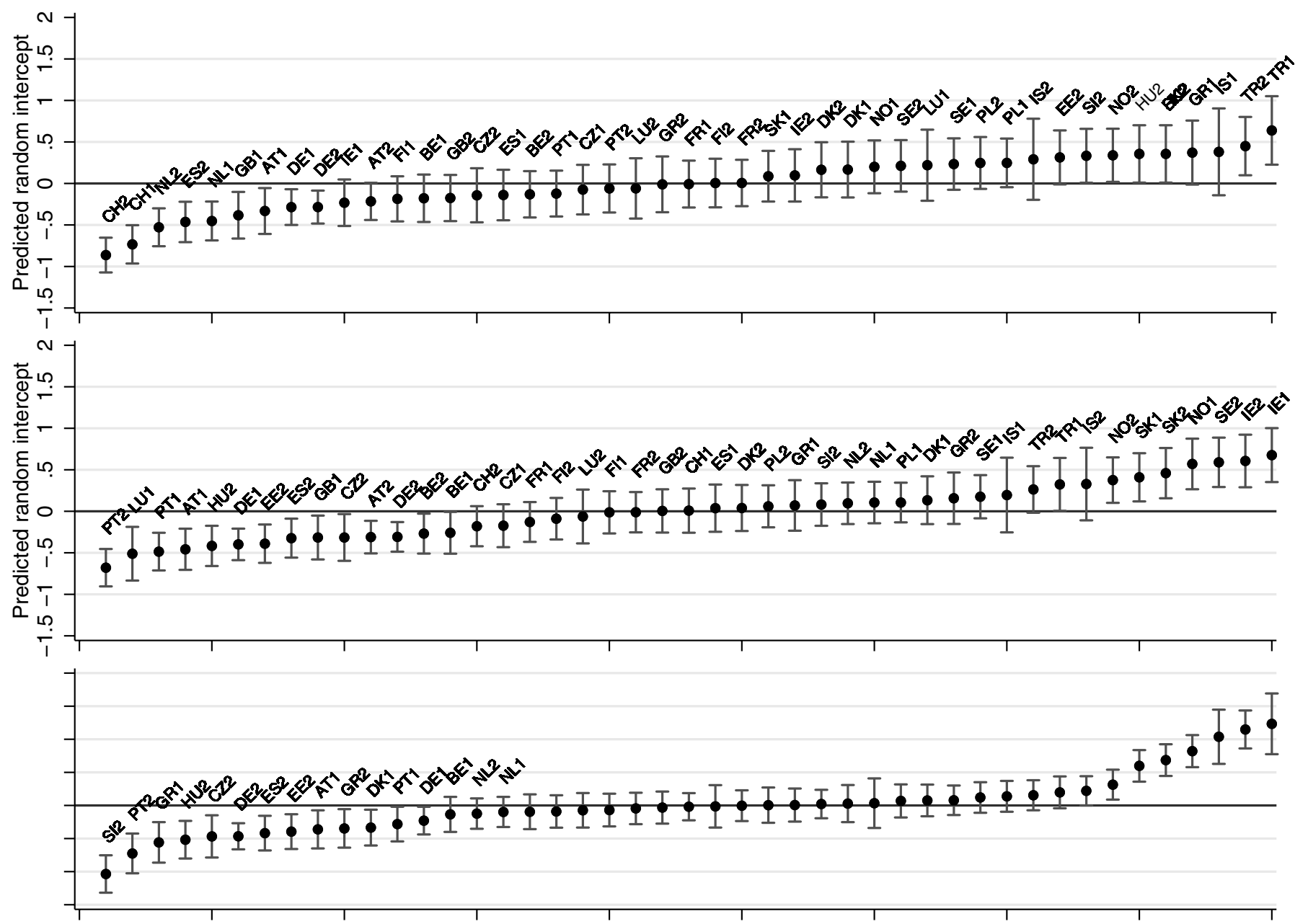

Fig. 2. Caterpillar plots for country level intercept residuals, first, second, third births hazards.

Estonia and Slovakia. Additionally, we observe that it varies between cohorts especially in Eastern European countries (for obvious reasons).

In order to measure the degree of rigidity of the labour market, the third indicator is EPL index on regular contracts, as measured by the OECD (OECD, 1999). In fact, theoretical and empirical studies on the impact of the EPL have often identified the strictness of EPL for individual and collective dismissals of permanent workers as the best proxy of labour market regulation (for a discussion Karabchuk, 2016). ${ }^{19}$ Overall, the average value is about 2.5 , and it is high in Portugal and low in Anglo-Saxon countries. The cohort-variation within country is especially clear in Spain and Finland.

The indicator of the level of diffusion of post-modernist orientation relates to the degree of religiousness at country-cohort level. It identifies the level of secularism, frequently defined as determining process of the adoption of post-modernist values (Lesthaeghe \& Surkyn, 1988). The gift of the argument here is that people who do not feel religious commitments are expected to be more oriented toward individual freedom of choice and, hence, more prompt to assume less conservative fertility behaviours. ${ }^{20}$ This indicator is built using the answer to the

\footnotetext{
${ }^{19}$ In particular it refers to procedural difficulties (e.g. length of notification period) and direct costs (severance payments) involved in dismissing permanent workers (Gebel and Giesecke, 2011). It takes also into account restrictions stemming from legislation, court rulings, collectively-bargained conditions of employment and customary practice (Venn 2009).

${ }^{20}$ This indicator has been validated by previous studies since the level of
}

question contained in WVS, waves 2, 3 and 4, "how important is in your life religion?". We have codified the answers in two categories, "important" or "not important". After that, we construct an indicator at the cohort-country level that represents the percentage of individuals (men and women) that do not think that religion is important. Doing so, we are able to (partly) identify a proxy of the proportion of adherents to post-modernist values for each country-cohort. The lower values are found in Turkey and Poland (about $20 \%$ ), the higher in Estonia (up to $80 \%)$ - country that has experienced an early trend toward secularization (see also Perelli-Harris, 2014). We observe a relevant cohort variation within country in Ireland, Austria and Spain.

Finally, in order to capture the diffusion of gender egalitarian ideals, we measure the proportion of people (men and women) that support gender egalitarian views regarding working women - see Arpino et al. (2015) and Bellani et al. (2017) for a discussion on the empirical validation as indicator of gender egalitarianism. ${ }^{21}$ This indicator derives from a question contained in EVS, waves 2 and 3, and in WVS, waves 2 , 3 and 4 . The respondent answers to the question about how much he/ she agrees with the statement "when jobs are scarce, men should have

\section{(footnote continued)}

religiousness constitutes a relevant component of value orientation of the SDT (Surkyn and Lesthaeghe, 2004)

${ }^{21}$ Although we use this variable to capture the degree to which gender egalitarianism characterizes any given society, we prefer to label it as 'gender equity' because it taps notions of fairness. 
Table 4

Results of Multilevel logistic regression on having at least one child on individual characteristics and country-cohort level variables. Odds ratios.

\begin{tabular}{|c|c|c|c|c|c|c|c|}
\hline Parity $1+$ vs 0 & Model 1 & Model 2 & Model 3 & Model 4 & Model 5 & Model 6 & Model 7 \\
\hline \multirow{2}{*}{ Age } & 1.010 & 1.011 & 1.011 & 1.010 & 1.011 & 1.011 & 1.010 \\
\hline & $(.012)$ & $(.012)$ & $(.012)$ & $(.013)$ & $(.012)$ & $(.012)$ & $-(.012)$ \\
\hline \multirow[t]{2}{*}{ Cohort } & 1.150 & $1.327^{* * *}$ & 1.192 & $1.669^{* * *}$ & $1.351 * *$ & 1.238 & $1.391 * * *$ \\
\hline & $(.166)$ & $(.18)$ & $(.162)$ & $(.252)$ & $(.178)$ & $(.163)$ & $(.168)$ \\
\hline \multicolumn{8}{|l|}{ Dataset: ESS (ref.) } \\
\hline \multirow[t]{2}{*}{ EVS } & 1.102 & 1.091 & 1.092 & 1.094 & 1.081 & 1.091 & 1.090 \\
\hline & $(.072)$ & $(.072)$ & $(.072)$ & $(.081)$ & $(.071)$ & $(.072)$ & $(.072)$ \\
\hline \multirow[t]{2}{*}{ WVS } & $1.320^{* * *}$ & $1.303^{* * *}$ & $1.305^{* * *}$ & $1.273^{* *}$ & $1.300^{* * *}$ & $1.310 * * *$ & $1.326^{* * *}$ \\
\hline & $(.123)$ & $(.122)$ & $(.122)$ & $(.13)$ & $(.121)$ & $(.122)$ & $(.123)$ \\
\hline \multicolumn{8}{|l|}{ Educational level: medium (ref.) } \\
\hline \multirow[t]{2}{*}{ Low } & $1.340^{* * *}$ & $1.346^{* * *}$ & $1.356^{* * *}$ & $1.295^{* * *}$ & $1.348^{* * *}$ & $1.357 * * *$ & $1.297 * * *$ \\
\hline & $(.089)$ & $(.09)$ & $(.09)$ & $(.096)$ & $(.09)$ & $(.091)$ & $(.087)$ \\
\hline \multirow[t]{2}{*}{ High } & $.717^{* * *}$ & $.730 * * *$ & $.735^{* * *}$ & $.701 * * *$ & $.720 * * *$ & $.746^{* * *}$ & $.718^{* * *}$ \\
\hline & $(.043)$ & $(.044)$ & $(.044)$ & $(.047)$ & $(.043)$ & $(.045)$ & $(.044)$ \\
\hline \multirow[t]{2}{*}{ HDI } & & $.973^{* *}$ & 0.995 & $.969 * * *$ & $.969 * * *$ & 0.985 & $.937 * * *$ \\
\hline & & $(.011)$ & $(.014)$ & $(.01)$ & $(.01)$ & $(.01)$ & $(.012)$ \\
\hline \multirow[t]{2}{*}{ Weighted leave weeks } & & $1.023^{* *}$ & $1.017^{*}$ & $1.018^{* *}$ & $1.029 * * *$ & $1.028 * * *$ & $1.017^{* *}$ \\
\hline & & $(.009)$ & $(.009)$ & $(.009)$ & $(.009)$ & $(.009)$ & $(.008)$ \\
\hline \multirow[t]{2}{*}{ Total family benefits } & & 0.989 & 1.046 & 1.070 & 0.940 & 0.937 & 1.148 \\
\hline & & $(.11)$ & $(.109)$ & $(.12)$ & $(.104)$ & $(.098)$ & $(.112)$ \\
\hline \multirow[t]{2}{*}{ Enrolment pre-primary } & & 0.999 & 0.999 & 0.999 & 0.999 & 1.002 & 1.001 \\
\hline & & $(.003)$ & $(.002)$ & $(.002)$ & $(.002)$ & $(.002)$ & $(.002)$ \\
\hline \multirow[t]{2}{*}{ Participation rate } & & 1.002 & 0.998 & $.988^{* *}$ & 1.003 & $1.010 * *$ & 1.005 \\
\hline & & $(.004)$ & $(.004)$ & $(.006)$ & $(.004)$ & $(.004)$ & $(.004)$ \\
\hline \multirow[t]{2}{*}{ Life-long single rate } & & $.902^{* * *}$ & $.911^{* * *}$ & $.918^{* * *}$ & $.910^{* * *}$ & $.880^{* * *}$ & 0.968 \\
\hline & & $(.026)$ & $(.024)$ & $(.027)$ & $(.026)$ & $(.026)$ & $(.026)$ \\
\hline \multirow[t]{2}{*}{ Proportion of women part-time } & & & $.989 * *$ & & & & \\
\hline & & & $(.004)$ & & & & \\
\hline \multirow[t]{2}{*}{ Size of public sector employment } & & & & $1.018^{* * *}$ & & & \\
\hline & & & & $(.006)$ & & & \\
\hline \multirow[t]{2}{*}{ EPL } & & & & & $.889 *$ & & \\
\hline & & & & & $(.061)$ & & \\
\hline \multirow[t]{2}{*}{ Diffusion postmodernism } & & & & & & $.988^{* * *}$ & \\
\hline & & & & & & $(.004)$ & \\
\hline \multirow[t]{2}{*}{ Gender egalitarianism } & & & & & & & $1.018^{* * *}$ \\
\hline & & & & & & & $(.004)$ \\
\hline \multirow[t]{2}{*}{ Gender egalitarianism $^{2}$} & & & & & & & $1.000 * * *$ \\
\hline & & & & & & & $(.000)$ \\
\hline Level 2 random-effects variance & $.132(.035)$ & $.060(.019)$ & $.047(.016)$ & $.034(.015)$ & $052(.017)$ & $.043(0.15)$ & $.030(.012)$ \\
\hline Observations & 15524 & 15524 & 15524 & 12376 & 15289 & 15136 & 15136 \\
\hline Number of groups & 45 & 45 & 45 & 36 & 43 & 43 & 43 \\
\hline
\end{tabular}

Note: *** $\mathrm{p}<0.01, * * \mathrm{p}<0.05,{ }^{*} \mathrm{p}<0.1$.

more right to a job than women". Answering categories were then scaled, with a first category indicating that the respondent disagrees or strongly disagrees, and the second category indicating if he/she agrees or strongly agrees or doesn't disagree with the statement. From this variable we construct a measure of support for gender egalitarianism as the percentage of gender egalitarian respondents at country-cohort level. In our models, this variable is measured in both linear and quadratic form. We observe in Table 3 that Turkey has the lowest value (about $36 \%$ ) while the highest is found in Iceland (about $95 \%$ ). Austria, Belgium together with France, Hungary and Poland exhibit a significant variation between cohorts.

In order to disentangle the influence of these factors, we control for structural and institutional variables at the country-cohort level. For capturing the generosity of family policies (e.g. Gauthier, 2007, LuciGreulich \& Thévenon, 2013), we include in our models three indicators (at country-cohort level), the weighted leave weeks measured as the total number of weeks of maternity weighted by the average normal net wages paid during the leave (from ILO Working Conditions Laws Database), the total family benefits as percentage of GDP (from OECD Social Expenditure Database), the gross enrolment to pre-primary education (from UNESCO). In order to account for economic development at country-cohort level, we control also for national Human Development Index (HDI) - retrieved from the UN Development Department. It represents a proxy of the national wealth (Myrskylä, Kohler, \& Billari, 2009) and of the general labour market conditions (United
Nations, 2010). Finally, we control for female participation rate at country-cohort level (as reported by ILOstat), representing the labour market opportunities that women face (Adsera, 2011a), ${ }^{22}$ and, lastly, for the prevalence of life long singlehood mirroring marriage market conditions. The construction of this indicator follows the definition suggested by Bellani et al. (2017) - lifelong singles as individuals that never ever cohabited or married until 40 years of age - and is based on our elaboration of ESS data (rounds 1-7) and EVS data (survey 2008). ${ }^{23}$

\subsection{Methodology}

Given the codification of the dependent variables and the hierarchical structure of the data, where individuals are nested within country-cohorts, we estimate multilevel (random effects) binary logistic models (Snijders \& Bosker, 1999). This methodology permits us to control (partly) for the correlation of the responses of individuals (first level) that belong to the same economic and cultural context (second level). While the first level in the model estimates individual-level correlates (women's characteristics) of completed fertility, the second

\footnotetext{
${ }^{22}$ Excluding this variable results do not substantially change (results upon request).

${ }^{23}$ Excluding this variable results do not substantially change (results upon request).
} 
Table 5

Results of multilevel logistic regression on having at least two children on individual characteristics and country-cohort level variables. Odds ratios.

\begin{tabular}{|c|c|c|c|c|c|c|c|}
\hline Parity $2+$ vs 1 & Model 1 & Model 2 & Model 3 & Model 4 & Model 5 & Model 6 & Model 7 \\
\hline Age & $\begin{array}{l}.985 \\
(.010)\end{array}$ & $\begin{array}{l}.985 \\
(.010)\end{array}$ & $\begin{array}{l}.985 \\
(.010)\end{array}$ & $\begin{array}{l}.985 \\
(.011)\end{array}$ & $\begin{array}{l}.986 \\
(.019)\end{array}$ & $\begin{array}{l}.988 \\
(.010)\end{array}$ & $\begin{array}{l}.988 \\
(.010)\end{array}$ \\
\hline Cohort & $\begin{array}{l}.901 \\
(.125)\end{array}$ & $\begin{array}{l}.820 \\
(.129)\end{array}$ & $\begin{array}{l}.797 \\
(.135)\end{array}$ & $\begin{array}{l}1.076 \\
(.169)\end{array}$ & $\begin{array}{l}.800 \\
(.115)\end{array}$ & $\begin{array}{l}.697^{* * *} \\
(.101)\end{array}$ & $\begin{array}{l}.798 \\
(.114)\end{array}$ \\
\hline \multicolumn{8}{|l|}{ Dataset: ESS (ref.) } \\
\hline EVS & $\begin{array}{l}1.121 * * \\
(.064)\end{array}$ & $\begin{array}{l}1.121^{* *} \\
(.064)\end{array}$ & $\begin{array}{l}1.121^{* *} \\
(.064)\end{array}$ & $\begin{array}{l}1.093 \\
(.069)\end{array}$ & $\begin{array}{l}1.106^{*} \\
(.063)\end{array}$ & $\begin{array}{l}1.128 * * \\
(.065)\end{array}$ & $\begin{array}{l}1.126^{* *} \\
(.065)\end{array}$ \\
\hline WVS & $\begin{array}{l}1.001 \\
(.079)\end{array}$ & $\begin{array}{l}.996 \\
(.078)\end{array}$ & $\begin{array}{l}.997 \\
(.078)\end{array}$ & $\begin{array}{l}1.022 \\
(.089)\end{array}$ & $\begin{array}{l}.989 \\
(.078)\end{array}$ & $\begin{array}{l}.999 \\
(.079)\end{array}$ & $\begin{array}{l}.999 \\
(.078)\end{array}$ \\
\hline \multicolumn{8}{|l|}{ Educational level: medium (ref.) } \\
\hline Low & $\begin{array}{l}1.282^{* * *} \\
(.072)\end{array}$ & $\begin{array}{l}1.283^{* * *} \\
(.073)\end{array}$ & $\begin{array}{l}1.284^{* * *} \\
(.073)\end{array}$ & $\begin{array}{l}1.275^{* * *} \\
(.080)\end{array}$ & $\begin{array}{l}1.298^{* * *} \\
(.075)\end{array}$ & $\begin{array}{l}1.285^{* * *} \\
(.075)\end{array}$ & $\begin{array}{l}1.267^{* * *} \\
(.074)\end{array}$ \\
\hline High & $\begin{array}{l}.947 \\
(.053)\end{array}$ & $\begin{array}{l}.943 \\
(.053)\end{array}$ & $\begin{array}{l}.944 \\
(.053)\end{array}$ & $\begin{array}{l}.916 \\
(.057)\end{array}$ & $\begin{array}{l}.932 \\
(.052)\end{array}$ & $\begin{array}{l}.939 \\
(.053)\end{array}$ & $\begin{array}{l}.927 \\
(.053)\end{array}$ \\
\hline HDI & & $\begin{array}{l}1.020 \\
(.015)\end{array}$ & $\begin{array}{l}1.025 \\
(.020)\end{array}$ & $\begin{array}{l}1.014 \\
(.012)\end{array}$ & $\begin{array}{l}1.008 \\
(.014)\end{array}$ & $\begin{array}{l}1.043^{* * *} \\
(.014)\end{array}$ & $\begin{array}{l}1.016 \\
(.018)\end{array}$ \\
\hline Weighted leave weeks & & $\begin{array}{l}.998 \\
(.011)\end{array}$ & $\begin{array}{l}.996 \\
(.012)\end{array}$ & $\begin{array}{l}.986 \\
(.009)\end{array}$ & $\begin{array}{l}1.010 \\
(.011)\end{array}$ & $\begin{array}{l}1.013 \\
(.010)\end{array}$ & $\begin{array}{l}.997 \\
(.010)\end{array}$ \\
\hline Total family benefits & & $\begin{array}{l}.945 \\
(.136)\end{array}$ & $\begin{array}{l}.959 \\
(.141)\end{array}$ & $\begin{array}{l}1.015 \\
(.128)\end{array}$ & $\begin{array}{l}.851 \\
(.113)\end{array}$ & $\begin{array}{l}.842 \\
(.106)\end{array}$ & $\begin{array}{l}.953 \\
(.127)\end{array}$ \\
\hline Enrolment pre-primary & & $\begin{array}{l}.997 \\
(.003)\end{array}$ & $\begin{array}{l}.997 \\
(.003)\end{array}$ & $\begin{array}{l}.997 \\
(.003)\end{array}$ & $\begin{array}{l}.999 \\
(.003)\end{array}$ & $\begin{array}{l}1.002 \\
(.003)\end{array}$ & $\begin{array}{l}1.001 \\
(.003)\end{array}$ \\
\hline Participation rate & & $\begin{array}{l}1.000 \\
(.005)\end{array}$ & $\begin{array}{l}.999 \\
(.005)\end{array}$ & $\begin{array}{l}.984^{* * *} \\
(.006)\end{array}$ & $\begin{array}{l}1.000 \\
(.005)\end{array}$ & $\begin{array}{l}1.004 \\
(.005)\end{array}$ & $\begin{array}{l}.997 \\
(.005)\end{array}$ \\
\hline Life-long single rate & & $\begin{array}{l}.989 \\
(.036)\end{array}$ & $\begin{array}{l}.990 \\
(.036)\end{array}$ & $\begin{array}{l}.991 \\
(.033)\end{array}$ & $\begin{array}{l}.975 \\
(.033)\end{array}$ & $\begin{array}{l}.910 * * * \\
(.032)\end{array}$ & $\begin{array}{l}1.025 \\
(.039)\end{array}$ \\
\hline Proportion of women part-time & & & $\begin{array}{l}.997 \\
(.006)\end{array}$ & & & & \\
\hline Size of public sector employment & & & & $\begin{array}{l}1.027^{* * *} \\
(.006)\end{array}$ & & & \\
\hline EPL & & & & & $\begin{array}{l}.768 * * * \\
(.064)\end{array}$ & & \\
\hline Diffusion postmodernism & & & & & & $\begin{array}{l}.982^{* * *} \\
(.004)\end{array}$ & \\
\hline Gender egalitarianism & & & & & & & $\begin{array}{l}1.007 \\
(.006)\end{array}$ \\
\hline Gender egalitarianism $^{2}$ & & & & & & & $\begin{array}{l}1.001^{* * *} \\
(.000)\end{array}$ \\
\hline Level 2 random-effects variance & $.138(.035)$ & $.129(.033)$ & $.128(.033)$ & $.059(.020)$ & $.095(.026)$ & $.084(.023)$ & $.089(.025)$ \\
\hline Observations & 13587 & 13587 & 13587 & 10854 & 13369 & 13228 & 13228 \\
\hline Number of groups & 45 & 45 & 45 & 36 & 43 & 43 & 43 \\
\hline
\end{tabular}

Note: $* * * \mathrm{p}<0.01, * * \mathrm{p}<0.05, * \mathrm{p}<0.1$

level of the model, fitting the country-cohorts level correlates, considers the intra-country-cohort correlation that is not controlled by aggregate level indicators. The random intercept represents unobserved characteristics that are shared within the individuals of the same second level unit. We use maximum-likelihood estimation with adaptive quadrature. As we have already reported, we control for the birth cohort by adding fixed effects for cohorts. ${ }^{24}$

Given that the country-level explanatory variables show, in some cases, a not negligible degree of correlation (see Appendix Table A2), we add them one by one in the main model.

\footnotetext{
${ }^{24}$ We opt for multilevel modelling because it is more appropriate for our study compared to standard regression analysis. First of all, in multilevel models the contribution to the log likelihood of each unit at level two is proportional to its size. Hence, since we have an unbalanced data structure, the choice of multilevel modelling is more appropriate because they can handle with heterogeneous size of the clusters (Skrondal and Rabe-Hesketh, 2004). Secondly, given that we include a cross-level interaction between education (at the individual level) and contextual variables, this methodology has the advantage that it allows the influence of education to vary across country-cohorts. It implies that we are able to assess the role that education exerts on the likelihood of women to have at least one, two or three children as well as to better understand the contextual factors that underlie fertility behaviour across educational classes. In this sense, individual controls, country-level indicators together with their interactions are all treated as independent variables in our models.
}

\section{Findings}

4.1. Descriptive results: heterogeneity in the educational gradient of fertility outcomes

Before turning to the test of the expectations of the theoretical models, some descriptive results will be discussed. The goal of this section is to describe the contextual variation in the educational gradient at specific parity. Fig. 1 displays the country-cohort educational gradient by plotting the estimated predicted probabilities of $\mathrm{P} 1+, \mathrm{P} 2+$ and P3 + . Note that the coefficients are obtained from binary logistic models that also contain individual controls.

We can observe that there is a substantial variation in the gradient and that it varies according to the parity considered. In most of the countries, better-educated women face lower probabilities associated to $\mathrm{P} 1+, \mathrm{P} 2+$ and $\mathrm{P} 3+$ when compared to those less educated. This is especially the case for Poland, Greece and Portugal, where the negative gradient is strong and persistent across parities. However, in other countries, the negative association appears to be small or null (e.g. Denmark, Sweden) or it has decreased across cohorts (e.g. Norway and Germany). At the same time, having an additional child appears to be less common for the younger cohort of highly educated women in Switzerland, Spain and Poland. This pattern is also found in Greece and Slovakia (for the P2+), while it seems the opposite in Austria, Belgium and Czech Republic (for P1+ and P2+). Also noteworthy are the 
Table 6

Results of multilevel logistic regression on having at least three children on individual characteristics and country-cohort level variables. Odds ratios.

\begin{tabular}{|c|c|c|c|c|c|c|c|}
\hline Parity $3+$ vs 2 & Model 1 & Model 2 & Model 3 & Model 4 & Model 5 & Model 6 & Model 7 \\
\hline Age & $\begin{array}{l}0.996 \\
(.009)\end{array}$ & $\begin{array}{l}0.996 \\
(.009)\end{array}$ & $\begin{array}{l}.996 \\
(.009)\end{array}$ & $\begin{array}{l}.988 \\
(.010)\end{array}$ & $\begin{array}{l}.994 \\
(.009)\end{array}$ & $\begin{array}{l}.995 \\
(.009)\end{array}$ & $\begin{array}{l}.995 \\
(.009)\end{array}$ \\
\hline Cohort & $\begin{array}{l}.845 \\
(.137)\end{array}$ & $\begin{array}{l}.921 \\
(.170)\end{array}$ & $\begin{array}{l}1.014 \\
(.199)\end{array}$ & $\begin{array}{l}1.005 \\
(.217)\end{array}$ & $\begin{array}{l}.927 \\
(.144)\end{array}$ & $\begin{array}{l}.744^{*} \\
(.130)\end{array}$ & $\begin{array}{l}.857 \\
(.138)\end{array}$ \\
\hline \multicolumn{8}{|l|}{ Dataset: ESS (ref.) } \\
\hline EVS & $\begin{array}{l}.947 \\
(.051)\end{array}$ & $\begin{array}{l}.947 \\
(.051)\end{array}$ & $\begin{array}{l}.946 \\
(.051)\end{array}$ & $\begin{array}{l}.993 \\
(.060)\end{array}$ & $\begin{array}{l}.941 \\
(.051)\end{array}$ & $\begin{array}{l}.956 \\
(.052)\end{array}$ & $\begin{array}{l}.954 \\
(.052)\end{array}$ \\
\hline WVS & $\begin{array}{l}.916 \\
(.067)\end{array}$ & $\begin{array}{l}.914 \\
(.066)\end{array}$ & $\begin{array}{l}.913 \\
(.066)\end{array}$ & $\begin{array}{l}.943 \\
(.076)\end{array}$ & $\begin{array}{l}.914 \\
(.066)\end{array}$ & $\begin{array}{l}.915 \\
(.067)\end{array}$ & $\begin{array}{l}.917 \\
(.067)\end{array}$ \\
\hline \multicolumn{8}{|l|}{ Educational level: medium (ref.) } \\
\hline Low & $\begin{array}{l}1.486^{* * *} \\
(.077)\end{array}$ & $\begin{array}{l}1.486^{* * *} \\
(.077)\end{array}$ & $\begin{array}{l}1.484^{* * *} \\
(.077)\end{array}$ & $\begin{array}{l}1.541^{* * *} \\
(.089)\end{array}$ & $\begin{array}{l}1.494^{* * *} \\
(.078)\end{array}$ & $\begin{array}{l}1.479 * * * \\
(.078)\end{array}$ & $\begin{array}{l}1.461^{* * *} \\
(.078)\end{array}$ \\
\hline High & $\begin{array}{l}.959 \\
(.052)\end{array}$ & $\begin{array}{l}.961 \\
(.052)\end{array}$ & $\begin{array}{l}.961 \\
(.052)\end{array}$ & $\begin{array}{l}.975 \\
(.060)\end{array}$ & $\begin{array}{l}.956 \\
(.052)\end{array}$ & $\begin{array}{l}.967 \\
(.053)\end{array}$ & $\begin{array}{l}.956 \\
(.052)\end{array}$ \\
\hline HDI & & $\begin{array}{l}1.001 \\
(.018)\end{array}$ & $\begin{array}{l}.981 \\
(.022)\end{array}$ & $\begin{array}{l}1.005 \\
(.017)\end{array}$ & $\begin{array}{l}.989 \\
(.015)\end{array}$ & $\begin{array}{l}1.027 \\
(.017)\end{array}$ & $\begin{array}{l}.990 \\
(.020)\end{array}$ \\
\hline Weighted leave weeks & & $\begin{array}{l}.977^{\star} \\
(.013)\end{array}$ & $\begin{array}{l}.982 \\
(.014)\end{array}$ & $\begin{array}{l}.980 \\
(.013)\end{array}$ & $\begin{array}{l}.995 \\
(.012)\end{array}$ & $\begin{array}{l}.991 \\
(.013)\end{array}$ & $\begin{array}{l}.975^{* * *} \\
(.011)\end{array}$ \\
\hline Total family benefits & & $\begin{array}{l}1.123 \\
(.196)\end{array}$ & $\begin{array}{l}1.069 \\
(.188)\end{array}$ & $\begin{array}{l}1.168 \\
(.217)\end{array}$ & $\begin{array}{l}.974 \\
(.145)\end{array}$ & $\begin{array}{l}.951 \\
(.153)\end{array}$ & $\begin{array}{l}1.125 \\
(.177)\end{array}$ \\
\hline Enrolment pre-primary & & $\begin{array}{l}.999 \\
(.004)\end{array}$ & $\begin{array}{l}.999 \\
(.004)\end{array}$ & $\begin{array}{l}.996 \\
(.004)\end{array}$ & $\begin{array}{l}.998 \\
(.003)\end{array}$ & $\begin{array}{l}1.003 \\
(.004)\end{array}$ & $\begin{array}{l}1.002 \\
(.003)\end{array}$ \\
\hline Participation rate & & $\begin{array}{l}1.000 \\
(.006)\end{array}$ & $\begin{array}{l}1.004 \\
(.007)\end{array}$ & $\begin{array}{l}.989 \\
(.009)\end{array}$ & $\begin{array}{l}1.000 \\
(.005)\end{array}$ & $\begin{array}{l}1.003 \\
(.006)\end{array}$ & $\begin{array}{l}.996 \\
(.005)\end{array}$ \\
\hline Life-long single rate & & $\begin{array}{l}.976 \\
(.043)\end{array}$ & $\begin{array}{l}.970 \\
(.042)\end{array}$ & $\begin{array}{l}.976 \\
(.047)\end{array}$ & $\begin{array}{l}.989 \\
(.037)\end{array}$ & $\begin{array}{l}.906^{* *} \\
(.041)\end{array}$ & $\begin{array}{l}1.045 \\
(.046)\end{array}$ \\
\hline Proportion of women part-time & & & $\begin{array}{l}1.010 \\
(.008)\end{array}$ & & & & \\
\hline Size of public sector employment & & & & $\begin{array}{l}1.016^{*} \\
(.009)\end{array}$ & & & \\
\hline EPL & & & & & $\begin{array}{l}.707 * * * \\
(.067)\end{array}$ & & \\
\hline Diffusion postmodernism & & & & & & $\begin{array}{l}.982^{* * *} \\
(.005)\end{array}$ & \\
\hline Gender egalitarianism & & & & & & & $\begin{array}{l}1.014^{* *} \\
(.006)\end{array}$ \\
\hline Gender egalitarianism $^{2}$ & & & & & & & $\begin{array}{l}1.001^{* * *} \\
(.000)\end{array}$ \\
\hline Level 2 random-effects variance & $.231(.056)$ & $.209(.051)$ & $.201(.049)$ & $.162(.045)$ & $.129(.033)$ & $.157(.040)$ & $.138(.035)$ \\
\hline Observations & 10753 & 10753 & 10753 & 8579 & 10592 & 10480 & 10480 \\
\hline Number of groups & 45 & 45 & 45 & 36 & 43 & 43 & 43 \\
\hline
\end{tabular}

Note: *** $\mathrm{p}<0.01, * * \mathrm{p}<0.05, * \mathrm{p}<0.1$.

differences in the gradient within countries. As Fig. 1 reveals, while, in some regions, the gradient increases with the transition to higher parities (e.g. Turkey) in others it seems not the case (e.g. France, Spain and the Netherlands).

Summarizing, over the observed period, European societies do not exhibit one single pattern in the gradient. Understanding the extent to which the different strength of the gradient can be explained by institutional and cultural factors is the challenge of our empirical analysis.

Before presenting the multilevel results, we estimate a baseline model in order to analyse cross-sectional differences in the likelihood of $\mathrm{P} 1+$, $\mathrm{P} 2+$ and $\mathrm{P} 3+-$ in this way we are able to measure country-cohort effects (estimated residuals). Results of this model are represented in Fig. 2. In these caterpillar plots we show country-cohort residuals that are ordered and endowed with $95 \%$ confidence bars $(+/-1.96$ the comparative standard errors) related to $\mathrm{P} 1+, \mathrm{P} 2+$ and $\mathrm{P} 3+$ respectively. We observe that for a substantial number of country-cohort units, the $95 \%$ confidence interval does not overlap the horizontal line at zero, indicating that the hazards are significantly above or below the mean.

In particular, considering the first plot (related to P1 +), we can see that Czech Republic, Netherlands and Spain (for different birth cohorts) are placed in the lowest part of the ranking meaning that, in these societies, the likelihood of becoming mother is lower than the average while the opposite is true for Iceland and Turkey (for different birth cohorts) that are placed at the top of the plot. Regarding higher parities $(\mathrm{P} 2+)$, we can see that the countries ranking high are the Nordic democracies (with the exception of Finland) along with France, Ireland and Turkey. Finally Fig. 2 shows that the likelihood of having more than two children (P3+) is especially lower in Mediterranean countries and Hungary (for different birth cohorts) and, again, higher for Turkey and Iceland.

\subsection{Multilevel results}

In the following, the results of the multilevel logistic models for $\mathrm{P} 1+, \mathrm{P} 2+$ and $\mathrm{P} 3+$ are presented. In a first step, $\mathrm{P} 1+, \mathrm{P} 2+$ and $\mathrm{P} 3+$ are regressed on individual characteristics. Then we add contextual variables as well as interaction terms testing the potential moderating association of institutional and attitudinal factors on the relationship between women's education and $\mathrm{P} 1+, \mathrm{P} 2+$ and $\mathrm{P} 3+$. The results of the regression analyses are presented as odds ratios (OR) together with their standard errors. As already explained, when interpreting parity progression, one should keep in mind unobserved differences between women at different parities as well as the relationship between family preferences and educational level attained.

In Model 1, Table 4,5 and 6, where we add individual level variables to the null model, we find a salient and significant influence of women's education (in line with previous literature). Women in the lower educational category show a greater likelihood of having an additional child compared to their high-educated counterpart. The predicted probability for women with low education of having at least one child is about $93 \%$ while it is less than $84 \%$ for highly educated. In the case of 
Table 7

Results of multilevel logistic regression on having at least one child on individual characteristics and country-cohort level variables interactions. Odds ratios.

\begin{tabular}{|c|c|c|c|c|c|}
\hline Parity $1+$ vs 0 & Model 1 & Model 2 & Model 3 & Model 4 & Model 5 \\
\hline \multirow[t]{2}{*}{ Age } & 1.011 & 1.009 & 1.010 & 1.010 & 1.010 \\
\hline & $(.0115)$ & $(.013)$ & $(.011)$ & $(.012)$ & $(.012)$ \\
\hline \multirow{2}{*}{ Cohort } & 1.210 & $1.630^{* * *}$ & $1.346^{* *}$ & 1.195 & $1.398^{* * *}$ \\
\hline & $(.164)$ & $(.243)$ & $(.177)$ & $(.158)$ & $(.170)$ \\
\hline \multirow[t]{2}{*}{ Dataset: ESS (ref.) EVS } & 1.094 & 1.095 & 1.082 & 1.091 & 1.086 \\
\hline & $(.072)$ & $(.081)$ & $(.071)$ & $(.072)$ & $(.072)$ \\
\hline \multirow[t]{2}{*}{ WVS } & $1.307^{* * *}$ & $1.276^{* *}$ & $1.299 * * *$ & $1.312^{* * *}$ & $1.317^{* * *}$ \\
\hline & $(.122)$ & $(.130)$ & $(.121)$ & $(.122)$ & $(.123)$ \\
\hline \multirow[t]{2}{*}{ HDI } & .992 & $.969^{* * *}$ & $.968^{* * *}$ & .989 & $.938 * * *$ \\
\hline & $(.014)$ & $(.011)$ & $(.011)$ & $(.011)$ & $(.012)$ \\
\hline \multirow[t]{2}{*}{ Weighted leave weeks } & $1.017^{* *}$ & $1.017^{* *}$ & $1.030^{* * *}$ & $1.028^{* * *}$ & $1.017^{* *}$ \\
\hline & $(.008)$ & $(.009)$ & $(.009)$ & $(.009)$ & $(.008)$ \\
\hline \multirow[t]{2}{*}{ Total family benefits } & 1.040 & 1.084 & .943 & .945 & 1.161 \\
\hline & $(.108)$ & $(.119)$ & $(.104)$ & $(.099)$ & $(.112)$ \\
\hline \multirow[t]{2}{*}{ Gross enrolment pre-primary } & .999 & 1.000 & .999 & 1.003 & 1.001 \\
\hline & $(.002)$ & $(.002)$ & $(.002)$ & $(.002)$ & $(.002)$ \\
\hline \multirow[t]{2}{*}{ Participation rate } & .998 & $.989 *$ & 1.003 & $1.012^{* * *}$ & 1.004 \\
\hline & $(.004)$ & $(.006)$ & $(.004)$ & $(.005)$ & $(.004)$ \\
\hline \multirow[t]{2}{*}{ Life-long single rate } & $.910 * * *$ & $.926^{* * *}$ & $.909^{* * *}$ & $.889^{* * *}$ & .970 \\
\hline & $(.024)$ & $(.026)$ & $(.025)$ & $(.026)$ & $(.027)$ \\
\hline \multicolumn{6}{|l|}{ Educational level: medium (ref.) } \\
\hline \multirow[t]{2}{*}{ Low } & $1.343^{* * *}$ & $1.268^{* * *}$ & $1.348^{* * * *}$ & $1.343^{* * *}$ & $1.315^{* * *}$ \\
\hline & $(.090)$ & $(.094)$ & $(.090)$ & $(.090)$ & $(.110)$ \\
\hline \multirow[t]{2}{*}{ High } & $.756^{* * *}$ & $.705^{* * *}$ & $.719 * * *$ & $.728 * * *$ & $.630 * * *$ \\
\hline & $(.047)$ & $(.047)$ & $(.044)$ & $(.045)$ & $(.048)$ \\
\hline \multirow[t]{2}{*}{ Proportion of women part-time } & $.991^{*}$ & & & & \\
\hline & $(.005)$ & & & & \\
\hline *low education & 1.002 & & & & \\
\hline & $(.004)$ & & & & \\
\hline *high education & .994 & & & & \\
\hline & $(.004)$ & & & & \\
\hline Size of public sector employment & & $1.017^{* * *}$ & & & \\
\hline & & $(.006)$ & & & \\
\hline *low education & & .991 & & & \\
\hline & & $(.006)$ & & & \\
\hline *high education & & $1.011^{*}$ & & & \\
\hline & & $(.006)$ & & & \\
\hline EPL & & & $.828^{* *}$ & & \\
\hline & & & $(.077)$ & & \\
\hline *low education & & & 1.132 & & \\
\hline & & & $(.103)$ & & \\
\hline *high education & & & 1.035 & & \\
\hline & & & $(.100)$ & & \\
\hline Diffusion post modernism & & & & $.988^{* * *}$ & \\
\hline & & & & $(.004)$ & \\
\hline *low education & & & & $.992^{* *}$ & \\
\hline & & & & $(.004)$ & \\
\hline *high education & & & & $1.006^{*}$ & \\
\hline & & & & $(.004)$ & \\
\hline Gender egalitarianism & & & & & $1.016^{* * *}$ \\
\hline & & & & & $(.005)$ \\
\hline *low education & & & & & .997 \\
\hline & & & & & $(.005)$ \\
\hline *high education & & & & & 1.004 \\
\hline & & & & & $(.005)$ \\
\hline Gender egalitarianism $^{2}$ & & & & & 1.000 \\
\hline & & & & & $(.000)$ \\
\hline *low education & & & & & 1.000 \\
\hline & & & & & $(.000)$ \\
\hline *high education & & & & & $1.001^{* *}$ \\
\hline & & & & & $(.000)$ \\
\hline Level 2 random-effects variance & $.045(.016)$ & $.031(.014)$ & $.052(.017)$ & $.043(.015)$ & $.029(.012)$ \\
\hline Observations & 15524 & 12376 & 15289 & 15136 & 15136 \\
\hline Number of groups & 45 & 36 & 43 & 43 & 43 \\
\hline
\end{tabular}

Note:***p $<0.01, * * \mathrm{p}<0.05, * \mathrm{p}<0.1$

$\mathrm{P} 2+$, it is about $83 \%$ and $77 \%$ for low and high educated women respectively, while in the case of $\mathrm{P} 3+$ the gap increases - the predicted probability is $48 \%$ for low educated and $38 \%$ for high educated.

In order to explore the overall association between the contextual level indicators and $\mathrm{P} 1+, \mathrm{P} 2+$ and $\mathrm{P} 3+$, we add to our model the variables at country-cohort level (Table 4,5 and 6). More specifically, we add to the individual variables the controls at country-cohort level (Model 2) and then, one by one, the country-cohort indicators in which we are interested in - the proportion of female part-time employment (Model 3), the share of female public employment (Model 4), the EPL index (Model 5), the degree of diffusion of post-modernist values (Model 6) and the proportion of people supporting egalitarian attitudes 
Table 8

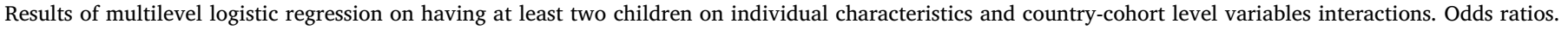

\begin{tabular}{|c|c|c|c|c|c|}
\hline Parity $2+$ vs 1 & Model 1 & Model 2 & Model 3 & Model 4 & Model 5 \\
\hline Age & $\begin{array}{l}.985 \\
(.010)\end{array}$ & $\begin{array}{l}.984 \\
(.011)\end{array}$ & $\begin{array}{l}.986 \\
(.010)\end{array}$ & $\begin{array}{l}.987 \\
(.010)\end{array}$ & $\begin{array}{l}.987 \\
(.010)\end{array}$ \\
\hline Cohort & $\begin{array}{l}.786 \\
(.134)\end{array}$ & $\begin{array}{l}1.080 \\
(.170)\end{array}$ & $\begin{array}{l}.797 \\
(.115)\end{array}$ & $\begin{array}{l}.679 * * * \\
(.100)\end{array}$ & $\begin{array}{l}.760^{*} \\
(.109)\end{array}$ \\
\hline Dataset: ESS (ref.) EVS & $\begin{array}{l}1.119 * * \\
(.064)\end{array}$ & $\begin{array}{l}1.092 \\
(.069)\end{array}$ & $\begin{array}{l}1.109 * \\
(.064)\end{array}$ & $\begin{array}{l}1.130 * * \\
(.065)\end{array}$ & $\begin{array}{l}1.127^{* *} \\
(.065)\end{array}$ \\
\hline WVS & $\begin{array}{l}.994 \\
(.078)\end{array}$ & $\begin{array}{l}1.018 \\
(.088)\end{array}$ & $\begin{array}{l}.989 \\
(.078)\end{array}$ & $\begin{array}{l}1.002 \\
(.079)\end{array}$ & $\begin{array}{l}.997 \\
(.079)\end{array}$ \\
\hline HDI & $\begin{array}{l}1.027 \\
(.020)\end{array}$ & $\begin{array}{l}1.011 \\
(.012)\end{array}$ & $\begin{array}{l}1.008 \\
(.014)\end{array}$ & $\begin{array}{l}1.047^{* * *} \\
(.014)\end{array}$ & $\begin{array}{l}1.019 \\
(.018)\end{array}$ \\
\hline Weighted leave weeks & $\begin{array}{l}.996 \\
(.012)\end{array}$ & $\begin{array}{l}.986 \\
(.009)\end{array}$ & $\begin{array}{l}1.010 \\
(.011)\end{array}$ & $\begin{array}{l}1.012 \\
(.010)\end{array}$ & $\begin{array}{l}.998 \\
(.010)\end{array}$ \\
\hline Total family benefits & $\begin{array}{l}.973 \\
(.144)\end{array}$ & $\begin{array}{l}1.019 \\
(.129)\end{array}$ & $\begin{array}{l}.850 \\
(.113)\end{array}$ & $\begin{array}{l}.849 \\
(.107)\end{array}$ & $\begin{array}{l}.969 \\
(.129)\end{array}$ \\
\hline Gross enrolment pre-primary & $\begin{array}{l}.997 \\
(.003)\end{array}$ & $\begin{array}{l}.997 \\
(.003)\end{array}$ & $\begin{array}{l}.999 \\
(.003)\end{array}$ & $\begin{array}{l}1.003 \\
(.003)\end{array}$ & $\begin{array}{l}1.001 \\
(.003)\end{array}$ \\
\hline Participation rate & $\begin{array}{l}1.000 \\
(.006)\end{array}$ & $\begin{array}{l}.984 * * \\
(.006)\end{array}$ & $\begin{array}{l}.999 \\
(.005)\end{array}$ & $\begin{array}{l}1.005 \\
(.005)\end{array}$ & $\begin{array}{l}.999 \\
(.005)\end{array}$ \\
\hline Life-long single rate & $\begin{array}{l}.993 \\
(.036)\end{array}$ & $\begin{array}{l}.991 \\
(.033)\end{array}$ & $\begin{array}{l}.973 \\
(.033)\end{array}$ & $\begin{array}{l}.918 * * \\
(.033)\end{array}$ & $\begin{array}{l}1.039 \\
(.040)\end{array}$ \\
\hline \multicolumn{6}{|l|}{ Educational level: medium (ref.) } \\
\hline Low & $\begin{array}{l}1.293^{* * *} \\
(.074)\end{array}$ & $\begin{array}{l}1.282^{* * *} \\
(.081)\end{array}$ & $\begin{array}{l}1.296^{* * *} \\
(.075)\end{array}$ & $\begin{array}{l}1.274 * * * \\
(.074)\end{array}$ & $\begin{array}{l}1.150^{*} \\
(.084)\end{array}$ \\
\hline High & $\begin{array}{l}.936 \\
(.052)\end{array}$ & $\begin{array}{l}.912 \\
(.057)\end{array}$ & $\begin{array}{l}.923 \\
(.052)\end{array}$ & $\begin{array}{l}.909 \\
(.053)\end{array}$ & $\begin{array}{l}.848^{* *} \\
(.062)\end{array}$ \\
\hline Proportion of women part-time & $\begin{array}{l}.999 \\
(.007)\end{array}$ & & & & \\
\hline *low education & $\begin{array}{l}.990 * * \\
(.004)\end{array}$ & & & & \\
\hline *high education & $\begin{array}{l}1.001 \\
(.004)\end{array}$ & & & & \\
\hline Size of public sector employment & & $\begin{array}{l}1.024^{* * *} \\
(.007)\end{array}$ & & & \\
\hline *low education & & $\begin{array}{l}1.007 \\
(.005)\end{array}$ & & & \\
\hline *high education & & $\begin{array}{l}1.008 \\
(.005)\end{array}$ & & & \\
\hline EPL & & & $\begin{array}{l}.794 * * \\
(.082)\end{array}$ & & \\
\hline *low education & & & $\begin{array}{l}.991 \\
(.083)\end{array}$ & & \\
\hline *high education & & & $\begin{array}{l}.868 \\
(.083)\end{array}$ & & \\
\hline Diffusion post modernism & & & & $\begin{array}{l}.982^{* * *} \\
(.005)\end{array}$ & \\
\hline *low education & & & & $\begin{array}{l}.995^{*} \\
(.003)\end{array}$ & \\
\hline *high education & & & & $\begin{array}{l}1.006^{*} \\
(.003)\end{array}$ & \\
\hline Gender egalitarianism & & & & & $\begin{array}{l}1.009 \\
(.006)\end{array}$ \\
\hline *low education & & & & & $\begin{array}{l}.994 \\
(.005)\end{array}$ \\
\hline *high education & & & & & $\begin{array}{l}.997 \\
(.004)\end{array}$ \\
\hline Gender egalitarianism $^{2}$ & & & & & $\begin{array}{l}1.000^{* * *} \\
(.000)\end{array}$ \\
\hline *low education & & & & & $\begin{array}{l}1.000 * * \\
(.000)\end{array}$ \\
\hline *high education & & & & & $\begin{array}{l}1.000^{*} \\
(.000)\end{array}$ \\
\hline Level 2 random-effects variance & .132 .034 & .059 .019 & .096 .026 & .084 .023 & .089 .025 \\
\hline Observations & 13587 & 10854 & 13369 & 13228 & 13228 \\
\hline Number of groups & 45 & 36 & 43 & 43 & 43 \\
\hline
\end{tabular}


Table 9

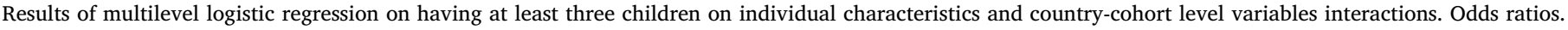

\begin{tabular}{|c|c|c|c|c|c|}
\hline Parity $3+$ vs 2 & Model 1 & Model 2 & Model 3 & Model 4 & Model 5 \\
\hline Age & $\begin{array}{l}0.995 \\
(0.009)\end{array}$ & $\begin{array}{l}0.988 \\
(0.010)\end{array}$ & $\begin{array}{l}0.994 \\
(0.009)\end{array}$ & $\begin{array}{l}0.995 \\
(0.009)\end{array}$ & $\begin{array}{l}0.995 \\
(0.009)\end{array}$ \\
\hline Cohort & $\begin{array}{l}0.989 \\
(0.197)\end{array}$ & $\begin{array}{l}1.004 \\
(0.217)\end{array}$ & $\begin{array}{l}0.923 \\
(0.143)\end{array}$ & $\begin{array}{l}0.730 * \\
(0.129)\end{array}$ & $\begin{array}{l}0.828 \\
(0.132)\end{array}$ \\
\hline Dataset: ESS (ref.) EVS & $\begin{array}{l}0.945 \\
(0.051)\end{array}$ & $\begin{array}{l}0.994 \\
(0.060)\end{array}$ & $\begin{array}{l}0.943 \\
(0.051)\end{array}$ & $\begin{array}{l}0.955 \\
(0.052)\end{array}$ & $\begin{array}{l}0.957 \\
(0.052)\end{array}$ \\
\hline WVS & $\begin{array}{l}0.909 \\
(0.066)\end{array}$ & $\begin{array}{l}0.945 \\
(0.076)\end{array}$ & $\begin{array}{l}0.914 \\
(0.066)\end{array}$ & $\begin{array}{l}0.916 \\
(0.067)\end{array}$ & $\begin{array}{l}0.924 \\
(0.068)\end{array}$ \\
\hline HDI & $\begin{array}{l}0.985 \\
(0.003)\end{array}$ & $\begin{array}{l}1.006 \\
(0.017)\end{array}$ & $\begin{array}{l}0.989 \\
(0.015)\end{array}$ & $\begin{array}{l}1.029^{*} \\
(0.018)\end{array}$ & $\begin{array}{l}0.991 \\
(0.020)\end{array}$ \\
\hline Weighted leave weeks & $\begin{array}{l}0.983 \\
(0.014)\end{array}$ & $\begin{array}{l}0.980 \\
(0.013)\end{array}$ & $\begin{array}{l}0.996 \\
(0.012)\end{array}$ & $\begin{array}{l}0.990 \\
(0.013)\end{array}$ & $\begin{array}{l}0.976^{* *} \\
(0.011)\end{array}$ \\
\hline Total family benefits & $\begin{array}{l}1.095 \\
(0.196)\end{array}$ & $\begin{array}{l}1.165 \\
(0.217)\end{array}$ & $\begin{array}{l}0.975 \\
(0.145)\end{array}$ & $\begin{array}{l}0.960 \\
(0.155)\end{array}$ & $\begin{array}{l}1.136 \\
(0.176)\end{array}$ \\
\hline Gross enrolment pre-primary & $\begin{array}{l}0.999 \\
(0.004)\end{array}$ & $\begin{array}{l}0.996 \\
(0.004)\end{array}$ & $\begin{array}{l}0.999 \\
(0.003)\end{array}$ & $\begin{array}{l}1.003 \\
(0.004)\end{array}$ & $\begin{array}{l}1.003 \\
(0.003)\end{array}$ \\
\hline Participation rate & $\begin{array}{l}1.005 \\
(0.007)\end{array}$ & $\begin{array}{l}0.989 \\
(0.009)\end{array}$ & $\begin{array}{l}1.000 \\
(0.005)\end{array}$ & $\begin{array}{l}1.004 \\
(0.006)\end{array}$ & $\begin{array}{l}0.997 \\
(0.005)\end{array}$ \\
\hline Life-long single rate & $\begin{array}{l}0.974 \\
(0.043)\end{array}$ & $\begin{array}{l}0.976 \\
(0.047)\end{array}$ & $\begin{array}{l}0.986 \\
(0.037)\end{array}$ & $\begin{array}{l}0.913^{* *} \\
(0.041)\end{array}$ & $\begin{array}{l}1.053 \\
(0.046)\end{array}$ \\
\hline Educational level: medium (ref.) Low & $\begin{array}{l}1.503^{* * *} \\
(0.078)\end{array}$ & $\begin{array}{l}1.549^{* * *} \\
(0.090)\end{array}$ & $\begin{array}{l}1.500 * * * \\
(0.079)\end{array}$ & $\begin{array}{l}1.462^{* * *} \\
(0.077)\end{array}$ & $\begin{array}{l}1.375^{* * *} \\
(0.096)\end{array}$ \\
\hline High & $\begin{array}{l}0.938 \\
(0.051)\end{array}$ & $\begin{array}{l}0.986 \\
(0.062)\end{array}$ & $\begin{array}{l}0.941 \\
(0.053)\end{array}$ & $\begin{array}{l}0.932 \\
(0.052)\end{array}$ & $\begin{array}{l}0.969 \\
(0.073)\end{array}$ \\
\hline Proportion of women part-time & $\begin{array}{l}1.013^{*} \\
(0.008)\end{array}$ & & & & \\
\hline *low education & $\begin{array}{l}0.986^{* * * *} \\
(0.003)\end{array}$ & & & & \\
\hline *high education & $\begin{array}{l}1.005 \\
(0.004)\end{array}$ & & & & \\
\hline Size of public sector employment & & $\begin{array}{l}1.018 * \\
(0.010)\end{array}$ & & & \\
\hline *low education & & $\begin{array}{l}0.997 \\
(0.004)\end{array}$ & & & \\
\hline *high education & & $\begin{array}{l}0.996 \\
(0.005)\end{array}$ & & & \\
\hline EPL & & & $\begin{array}{l}0.699 * * * \\
(0.080)\end{array}$ & & \\
\hline *low education & & & $\begin{array}{l}1.041 \\
(0.091)\end{array}$ & & \\
\hline *high education & & & $\begin{array}{l}0.917 \\
(0.095)\end{array}$ & & \\
\hline Diffusion post modernism & & & & $\begin{array}{l}0.982^{* * *} \\
(0.006)\end{array}$ & \\
\hline *low education & & & & $\begin{array}{l}0.997 \\
(0.003)\end{array}$ & \\
\hline *high education & & & & $\begin{array}{l}1.008^{* *} \\
(0.003)\end{array}$ & \\
\hline Gender egalitarianism & & & & & $\begin{array}{l}1.013^{* *} \\
(0.007)\end{array}$ \\
\hline *low education & & & & & $\begin{array}{l}0.998 \\
(0.003)\end{array}$ \\
\hline *high education & & & & & $\begin{array}{l}1.010^{* * *} \\
(0.004)\end{array}$ \\
\hline Gender egalitarianism $^{2}$ & & & & & $\begin{array}{l}1.001^{* * *} \\
(0.000)\end{array}$ \\
\hline *low education & & & & & $\begin{array}{l}1.000 \\
(0.000)\end{array}$ \\
\hline *high education & & & & & $\begin{array}{l}1.000 \\
(0.000)\end{array}$ \\
\hline Level 2 random-effects variance & .207050 & .163 .045 & .129 .033 & .159 .041 & .132 .034 \\
\hline Observations & 13587 & 10854 & 13369 & 13228 & 13228 \\
\hline Number of groups & 45 & 36 & 43 & 43 & 43 \\
\hline
\end{tabular}

Note: $* * * \mathrm{p}<0.01, * * \mathrm{p}<0.05, * \mathrm{p}<0.1$. 

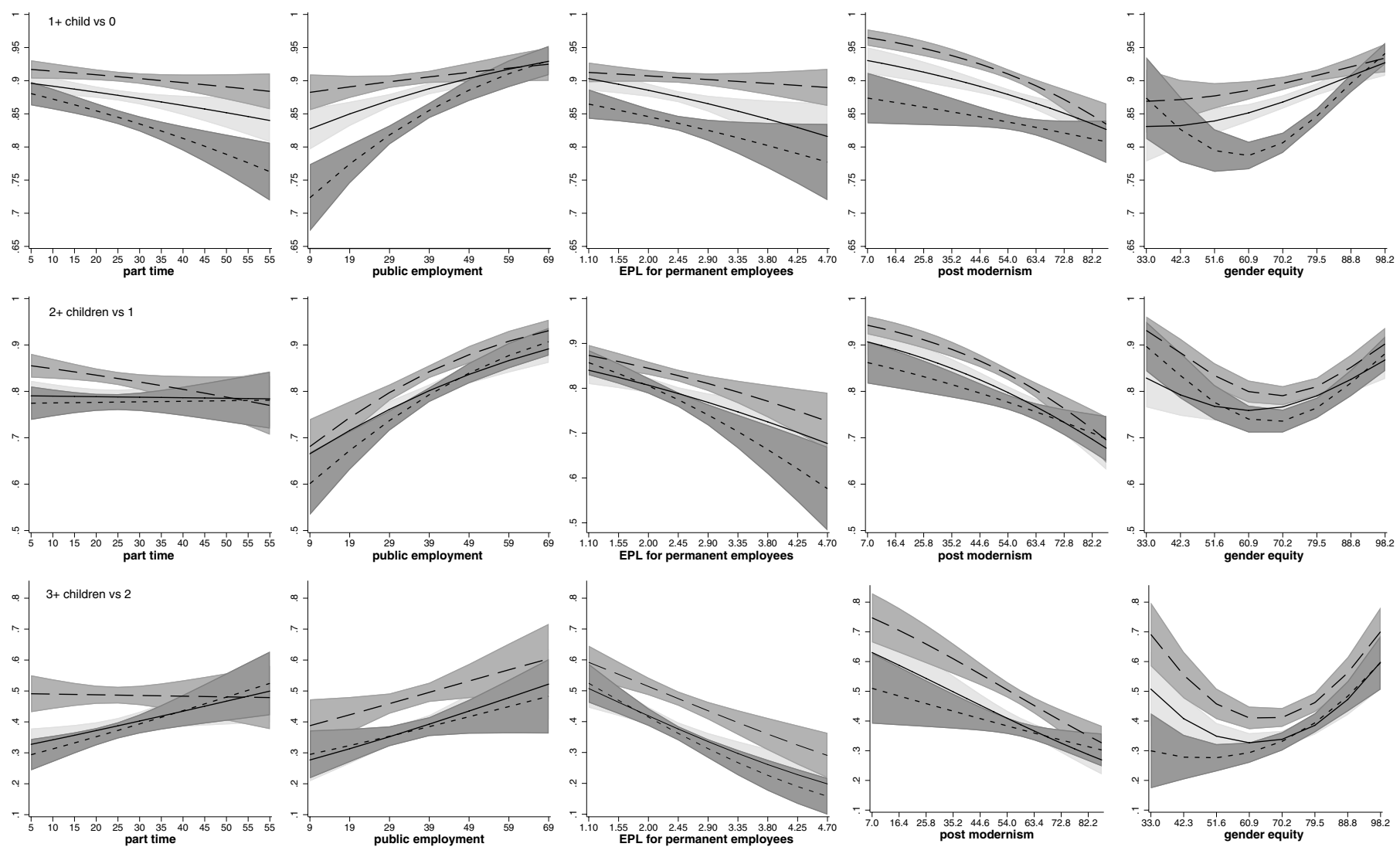

high - . - -

low - -

medium

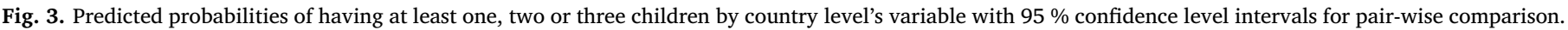

and its squared term (Model 7). ${ }^{25}$ All these variables are centred around the mean to ease the interpretation of their coefficients.

Finally, in Table 7,8 and 9, we include in the models the cross-level interactions of the aggregate variables by the women's educational level.

\subsubsection{Part-time employment}

Model 3 of Table 4 shows that the share of part-time employment is negatively associated to the odds of having at least one child (odds ratios

\footnotetext{
${ }^{25}$ The quadratic term is included in this model because a correct empirical test of the Multiple Equilibrium theory on fertility behaviour requires the inclusion in the model specification of the squared term of gender egalitarianism as a covariate (e.g. Arpino et al., 2015). In fact, one of the main propositions of the theory of Esping-Andersen and Billari (2015 is that "fertility or marital stability will decline as the traditional equilibrium erodes and no new normative regime has taken its place. When a new stable equilibrium gains ground, we should see a return to outcomes that are more equitable and that better match individual preferences". An empirical test of the post-modernist variant of the SDT theory on fertility does not need a quadratic term of the indicator(s) of post-modernism since it does not conceive any U-shaped association between post-modernism and fertility (or other demographic outcomes considered). Inspired by the rise of Post-Materialism (Inglehart, 1971), proponents of this theory expect that different pace of secularization corresponds to different level of fertility in a sort of a continuous gradual change. More specifically, they theorize that the emergence of secularization would bring to a reduction of the level of fertility (van de Kaa, 2001). In this sense the transition would lead to a decrease in fertility "the cohort fertility [...] is expected to reach a maximum value well below replacement" (van de Kaa, 2002: 10). Thus, we have not found any empirical article on the association between post-modernism and fertility testing a U-shaped relationship (e.g. Aassve, Sironi, \& Bassi, 2011; Brons, Liefbroer, \& Ganzeboom, 2017; Merz \& Liefbroer, 2012).
}

of 0.989 , with $\mathrm{p}<0.05$ ), also when taking individual characteristics into account. In contrast, the coefficient is not significantly associated with $\mathrm{P} 2+$ and P3+ (Model 3 Tables 5 and 6). This result points out that, overall, women are not more likely to have an additional child where the prevalence of part-time employment is higher. In other words, our findings, similarly to Baizán, Arpino, and Delclós (2016)), seem not consistent with the idea that a (relatively) high quantity of part time jobs embodies an appealing response to low fertility tout court. Whether the quality and not the quantity of part time jobs represents a better indicator is a matter that our data do not allow us to further investigate. However, since a higher availability of part-time jobs goes hand in hand with a lower quality of part-time positions (Del Boca \& Sauer, 2009), we convey that we observe a negative association between this macro-dimension and $\mathrm{P} 1+$ merely because we are capturing this specific aspect.

We then include to our model an interaction term to explore whether the association varies according to women's educational level (Model 1 of Tables 7,8 and 9). Two noticeable observations emerge from this interaction, when we focus on first parity. First, the degree to which women have accesses to part-time jobs is negatively associated with the likelihood of having at least one child for all the educational groups (.991 $\mathrm{p}<0.10$ ). Second, this association seems more relevant for better-educated women; in other words, a higher prevalence of part time jobs is accompanied by a higher educational differential in childlessness compared with low educated women. ${ }^{26}$ However, regarding P2+, a

\footnotetext{
${ }^{26}$ We find that the comparison of the part-time availability slopes for medium versus low educated is not significant $(\mathrm{p}=0.594)$. However, the test comparing the slopes of high educated versus low educated women is significant $(\mathrm{p}=0.059)$.
} 
negative relationship of the spread of part-time work is found only for lower educated women (for other educational categories the coefficient is not significant). We find a positive association with P3 + for medium and highly educated women - while it is not significant for lower educated.

To convey a sense of the magnitude of these results, we estimate and illustrate in Fig. 3 the predicted probabilities of $\mathrm{P} 1+, \mathrm{P} 2+$ and $\mathrm{P} 3+$ for the three educational groups on different levels of female part-time employment based on Model 1 of Tables 7,8 and 9. We can see in Fig. 3 (first column of the first panel) that, for all the educational groups, the probability of having at least one child is lower in countries with a high prevalence of part-time employment (corresponding to the observed value in Netherlands and Switzerland) than in countries characterised by a low availability (corresponding to the observed value for a group of Eastern European countries).

The educational gap in childlessness is found in countries with low and medium but also high level of part-time employment, where it is especially pronounced. We observe that, in the case of an increase of the rate of part time from $5 \%$ to $55 \%$, the predicted probability of having at least one child for the class of tertiary educated is associated with a decrease from about $87 \%$ to about $76 \%$ (while for the class of lower educated it falls from $92 \%$ to $88 \%$ ). Thus, extensive part-time employment is associated with a higher quota of childless women and, in parallel, with a wider educational ladder.

At the opposite pole, the availability of part-time employment is related to $\mathrm{P} 2+$ for the sole group of lower educated women, employing a depressing role on their chances of having at least two children - note that the magnitude of the related coefficient is slight. Moreover, we observe that a substantial educational gap for P2 + characterizes only countries with a low level of part time jobs since it disappears in societies where the availability of part-time positions is relatively high. In such a context, low and high-educated women have similar propensities of being mother for the second time. However, when we focus on P3+, we observe a jump from $30 \%$ to $50 \%$ of the corresponding predicted probabilities for higher educated (and also for middle educated) - while we do not observe any changes for lower educated women.

Conversely, the empirical results suggest that part-time availability is heterogeneously associated with the final number of parities since this relationship varies according to the educational group and the outcome variable considered.

Broadly speaking, we see that an increment of part-time positions is not per se a valid instrument to increase fertility outcomes. Thus, there is little support for the claim that creation of part-time positions is an incontrovertible policy tool supporting simultaneously the reproductive behaviour and the reduction of the educational gradient. Our analyses seem to suggest, instead, that the availability of part-time employment has a positive association with childlessness and with an expansion of its gradient. The marked relationship between part-time availability and childlessness for highly educated could be explained by part-time job as synonymous of lower paying occupations and less career development (Del Boca \& Sauer, 2009). Furthermore, since a high prevalence of part-time jobs is consistent with the diffusion of male breadwinner/ female part-time career model (Pfau-Effinger, 2005), highly educated women may find more difficult to establish themselves as equal (or first) earner where female employment is dominated by part-time jobs. In this kind of context, one possible strategy adopted by higher educated women to avoid career penalties is to withdraw motherhood in order to maintain less common full-time positions.

These considerations cannot be directly applied to the selected population of women who have already become mothers. In this case, we find that the share of part-time jobs is associated with the absence of a gradient for both $\mathrm{P} 2+$, depressing low educated propensities, and P3+, enhancing high and middle educated propensities. Accordingly, we convey that male breadwinner/female part-time career model is not negatively associated with higher order parities for better educated. The one and half model seems not in conflict with the likelihood of having higher order births at least for those with higher human capital.

\subsubsection{Public sector employment}

Model 4 of Table 4-6 shows that the relationship between the size of public employment and first, second and third(plus) births is overall positive and that the related coefficients are statistically significant. This indicates that women living in countries with a more extensive public sector employment are more likely to have larger family compared to women of other countries. The higher magnitude of the coefficient is observed for the P2+ (odds ratio of $1.027 \mathrm{p}<0.01$ ) while it is slightly weaker for $\mathrm{P} 1+(1.018 \mathrm{p}<0.01)$ and for $\mathrm{P} 3+(1.016 \mathrm{p}<0.1)$. This result is in line with the idea of the state as employer and family-work reconciliation catalyst (Adsera, 2005): the 'insurance' of job stability in case of motherhood and the provision of family support are likely to make easier for women to become mothers and to have large families.

When exploring whether this association varies according to women's educational level (Model 2 of Table 7-9), we find that it is stronger for higher educated women when we consider P1 + . In other words, we observe that an increase in the availability of public sector employment is associated with a decrease of childlessness and with a weakening of the educational divide (Fig. 3, second column, first panel). More specifically, whereas in contexts (such as Luxemburg) with a limited public sector employment, higher educated women have a probability of about $73 \%$ of having at least one child (versus $88 \%$ for low educated) in the case of societies with extended public sector jobs (such as Iceland) the equivalent probability is higher than $90 \%$ - the same predicted probability as for lower educated.

While public sector employment is positively associated with P2+ and P3+, we do not observe, for the same outcomes, any significant reduction in the educational gradient related to the increase of public employment. These results indicate that, in a context of an extensive public sector employment, second and third motherhoods seems to get more 'affordable' for all the educational groups.

Broadly speaking, our empirical evidence is likely to challenge the theoretical tenets of the welfare state paradox argument according to which higher public employment levels come at the expense of opportunities for high-educated women. We instead observe that a higher supply of public employment is positively associated with reproductive choices especially for women with higher income potential. The latent underlined mechanism is that a higher availability of public sector jobs translates into a reduction of the indirect costs of motherhood (Rønsen \& Skrede, 2010). Moreover, where public sector employment is a more common option, women may feel more secure about their future, thus perceiving better conditions for become mothers (Martin Garcia \& Castro-Martin, 2013). Therefore, public employment seems to be associated to a rebound fertility. In response to the continuous political attacks against public sector (as reported by Laird, 2017), our findings suggest that public employment (as a work-life balance) instrument looks like a potential resource for fertility recover. Moreover, we show that it is likely to hamper educational gap in childlessness.

\subsubsection{Strictness of EPL}

Tables 4-6 show that the relationship between the level of strictness of EPL and P1 +, P2 + and P3 + is negative and that all the related coefficients are statistically significant (Model 5 Tables 4-6).

In line with previous studies (Adsera, 2005), our results confirm that women tend to have lower parity progressions as the degree of rigidity of labour market increases. Overall, this result suggests that a rigid labour market regulation is associated with unfavourable conditions for childbearing. The coefficient size appears particularly large for P2+ (odds ratio .768, $\mathrm{p}<0.01$ ) and $\mathrm{P} 3+$ (odds ratio .707, $\mathrm{p}<0.01$ ), while it is slightly smaller for $\mathrm{P} 1+$ (odds ratio $.889, \mathrm{p}<0.1$ ), indicating that the proportion of first-, second- and third-time mothers is smaller in contexts with highly regulated labour markets.

We then explore whether the relationship between EPL and fertility outcomes varies according to the educational level of the female respondent. The cross-level interaction between the level of EPL and women's education (Model 3 Tables 7-9) indicates that there is not any change for 
the negative gradient associated to the level of EPL (around the mean).

Fig. 3 (third column) does not show any recovering association between EPL and $\mathrm{P} 1+, \mathrm{P} 2+$ and $\mathrm{P} 3+$ for higher educated women compared to low-educated. Moreover, we observe from the Fig. 3 that the negative educational gradient is particularly evident for mediumhigh level of EPL for all the outcomes.

One could convey that rigid strict regulation of labour markets, mainly designed to protect mature male workers (Rueda, 2005), is likely to hinder fertility realizations for all the women's educational groups. However, the motivations behind the decision to limit family size under strict EPL may be different for low and high-educated women. In the case of low educated women, children may get less affordable within contexts of limited job stability and poorer working conditions. Higher educated women, even if less at risk to be trapped in poorly-protected labour market segment (Mills \& Blossfeld, 2013), may have the perception that motherhood exposes them to the risk to be excluded by firm-internal promotions (Brinton \& Lee, 2016). As a consequence, strict EPL, hampering the dual role of mother and -worker, may lead women with college education to be more likely to bypass fertility desires.

\subsubsection{Post-modernist variant of SDT}

In Tables 4-6 (Model 4) we observe that, for all the outcome variables considered, there is a negative association with the level of secularization - as a proxy of post-modernist attitudes.

Given the large percentage of people who adopt post-modernist attitudes (from about $7 \%$ to about $82 \%$ ) the apparent small odds ratios suggest instead a not negligible relationship - particularly for higher parities. Consistent with SDT predictions, our findings show that in more secular societies, where the normative disapproval of childlessness and of small families is weaker (Koropeckyj-Cox \& Pendell, 2007), the probability of having one or more children is lower.

However, when focusing on the interactions between the macrolevel variable and women's education (Tables 7-9, Model 3), one should note that the childbearing patterns of women with low education are dissimilar to those with higher educated levels (Model 3 Table 7).

To ease the interpretation, the graphs in Fig. 3 plot the predicted probability of $\mathrm{P} 1+, \mathrm{P} 2+$ and $\mathrm{P} 3+$ by educational level and by the degree of post-modernism. Calculations suggest that highly educated women have lower predicted probabilities associated with $\mathrm{P} 1+, \mathrm{P} 2+$ and $\mathrm{P} 3+$, compared to their low- education counterparts - when they live in contexts characterised by a narrow diffusion of post-modernist attitudes. ${ }^{27}$ We can also see, in Fig. 3, that the predicted differences between high and low educated women are estimated with a higher statistical precision around average values of the macro level variable (as shown by the confidence interval). This means that in societies where about half of the population adhere to secular values, the educational divide is likely to be more definite. Our findings describe, overall, a restriction of the educational differentials for all the parities in contexts where the adoption of post-modernist value orientation is far-reaching (where about more than $80 \%$ of the population accept post-modernist orientations). These results are likely to be consistent with the expectation of the post-modernist variant of the SDT theory about the decline of the educational gradient in 'less altruistic' societies.

However, when we look more closely at the data, we note that the decline is more evident for the reproductive choices of the group of less educated women, a result that diverges somewhat from the theoretical predictions. In fact, we can see that - for women with a college education - the predicted probability of $\mathrm{P} 1+$ for average level of postmodernism is about $84 \%$ while it is about $82 \%$ for the maximum level

\footnotetext{
${ }^{27}$ It has to be noted that the indicator we use refers to secularism, that is one dimension of post-modernism. Data limitations hinder the use of a composite index of post-modernism.
}

(the difference is not statistically significant); these values are about 94 $\%$ and $84 \%$, respectively, for low-educated women (the difference is statistically significant).

Thus, whereas highly-educated women are identified as the front runners of individualistic values and practices also in fertility behaviour (Lesthaeghe \& Surkyn, 2007), the emergence and the diffusion of postmodernist values does not seem to be a strong predictor of their birth progressions, indicating that this group seems only marginally reactive to the variability of this contextual factor. The rise and the diffusion of post-modernist values (Lesthaeghe, 2010) appears to be more related to the fertility choices of women with less education.

We convey that, as the choice of parenthood becomes more detraditionalised, women with less human capital are likely to lose their advantages in parity progression. As some scholars (Mills, Blossfeld, \& Klijzing, 2005; Perelli-Harris et al., 2010) have acknowledged, women with less education living in countries characterised by a weakening of the family as an institution have faced the major alteration of traditional patterns of family life (see also Lichter, Turner, \& Sassler, 2010). Hence, in societies characterised by a high degree of post-modernism, poorly educated women seem less likely to convert their intimate relationships into long-term commitments. The ultimate outcome for low educated women is an exceptional increase in childlessness and a decrease in parity progression - as suggested by our empirical findings. Additionally, since the disruption of traditional values goes hand in hand with the emerging preference for a more consumption-oriented lifestyle, women with less education are likely to become less attractive in the marriage market (Goldscheider et al., 2015; Oppenheimer, 1995). This seems not be the case for highly educated women, themselves advantaged by their better economic prospects (Stevenson \& Wolfers, 2007; Wilk, 1991).

\subsubsection{Multiple equilibrium}

We estimate multilevel models to test whether the probability of having at least one, two or three(plus) children varies by the degree of acceptance of gender egalitarianism. As will be recalled, the Multiple Equilibrium framework predicts a U-shape relationship. And indeed, the estimations reported in Tables 4-6, Model 7, show a better fit when we additionally include a squared term of the gender egalitarianism indicator. The coefficient of the squared term is positive and statistically significant for all the models. For P1 + and P $3+$ also the linear term is positive and statistically significant while this is not the case for $\mathrm{P} 2+$.

Tables 7-9 report the micro-macro interaction associations between women's education and the gender egalitarianism variable (and its square). This serves to test whether higher education for women is strictly associated to the level of gender equity in their fertility decisions.

Focusing on $\mathrm{P} 1+$, Table 7 , Model 5 shows a positive and statistically significant interaction of the squared term of the contextual variable only with the category corresponding to tertiary education. The results are somewhat different for $\mathrm{P} 2+$ and $\mathrm{P} 3+$.

To ease interpretation of the results, Fig. 3 (last column) plots the predicted probabilities related to $\mathrm{P} 1+, \mathrm{P} 2+$ and $\mathrm{P} 3+$ by education for different levels of gender egalitarianism. When we focus on $\mathrm{P} 1+$, the graph shows that the U-shape pattern mirrors only higher educated women's propensities. The relationship between gender equity and $\mathrm{P} 1+$ is initially negative and then turns positive only for this educational group. We observe also that when gender egalitarianism assumes values close to the average, tertiary educated women have the lowest probability of $\mathrm{P} 1+$ (the predicted probability is $77 \%$ and it is about 12 percentage points lower than less educated). Predicted probabilities are similar between the two groups in case of both low and extremely high levels of the macro variable. Interestingly, focusing on low educated women, we do not find any statistically significant difference in their probability of being childless along the distribution of the contextual factor. 
In the case of $\mathrm{P} 2+$, we find a U-shape relationship for all the educational groups, that is especially marked for higher educated. We observe a negative gradient only for societies characterised by average value of acceptance of gender egalitarianism. In other words, low or high levels of approval of gender egalitarianism are associated with a higher likelihood of $\mathrm{P} 2+$ that also leads to a reduction of the gradient.

Focusing on the last panel, it turns out that, for that macro variable, there is not a U-shape relationship in the case of P3 + for higher educated women- while this is the case for lower educated. Highly and lowly educated have similar chances to have a third child only where the level of gender egalitarianism is far above its average value, and not where it is below.

In summary, the expectations of Multiple Equilibrium framework find consistent empirical support in our analysis. In fact, we observe that living in contexts with low or high levels of gender egalitarianism is overall associated with both higher progression rates and to a small gradient - while the opposite is true for societies characterised by partial support.

This final set-up result reinforces the impression of a sharp educational gap in fertility outcomes in countries that are posited in a socalled Unstable Equilibrium. Instead, when embedded in contexts characterised by a dominance in beliefs about women's proper roles, no matter whether they are traditional or egalitarian, higher and lower educated women generally experience similar fertility outcomes.

We convey that, as long as gender roles are strongly dominated by a traditional family model and partners' specialisation - as is supposed to be the case for societies characterised by a low gender-egalitarianism approval, women's domestic and caring duties are strictly defined and univocal (Bellani et al., 2017). This may be the reason why, in traditional societies, we observe that both high- and low-educated women conform to societal expectations by having at least two children. In parallel, in contexts where gender egalitarianism has gained dominance, a universal support of new gender orientation is likely to contribute to the construction of an innovative model of partnership based on an egalitarian-based, dual earners - dual career couple. On this view, women with university-level education are less likely to renounce motherhood. In such a context, men strongly legitimate the notion of mother working and, further, express preferences for their own active participation in the unpaid work, comprising childcare. Hence, antitraditionalist attitudes about gender roles seem to play a key-role for a rebound of fertility accompanied by a decrease of the educational gradient.

\subsection{Robustness checks}

Although for the purpose of this article we are more interested in cross-national than cross-temporal variation in gender egalitarianism, we demonstrate the robustness of our findings controlling for betweencountry heterogeneity by adding to our models fixed-effects for countries. In this way, we consider only the within (longitudinal) variation in contextual variables. Thus, we estimate two-level models with individuals nested into country-cohort and with the inclusion of country fixed-effects, aimed at capturing country-level time invariant factors. Given that fixed-effects capture macro characteristics of the countries, we do not to include macro-level controls. One of the advantages of this approach is that we can test whether the relationships between gender egalitarianism and $\mathrm{P} 1+, \mathrm{P} 2+$ and $\mathrm{P} 3+$ are robust to the presence of country-level, time-invariant factors, i.e. this association is not biased even in the presence of these unobserved confounders. Note that the potentiality of this approach is, however, limited by the low variance of gender egalitarianism in its across-time component. Table A3 and the corresponding Fig. A1 (where we reported predicted probabilities for each parity) show that the moderator role played by gender egalitarianism on the educational gradient is only marginally affected by the inclusion of country fixed-effects (as compared to the main results presented in Tables 7,8 and 9). Results are supported also when we introduce into the model an interaction between country dummies and educational level (see in the Appendix, Table A6 and Fig. A4). ${ }^{28}$ As an additional robustness check, we ran supplementary models controlling also for the interaction between education and one of the contextual variables considered as moderators. Models in Table A4 (Models 1-4) replicates the specification of Tables 7-9, column 5 by including, one at a time, the interactions between education and level of part-time employment (Model 1), level of public employment (Model 2), EPL (Model 3 ), and level of post modernism (Model 4). The sign and the magnitude of the coefficients of interest are not affected by the inclusion of these controls. The predicted probabilities represented in Fig. A2 confirm the view that the educational gradient varies according to the level of gender egalitarianism, thus suggesting there are not fundamental differences with the results presented in the previous section. The only exception is related to Model 2 of Table A4 (see related predicted probabilities of Fig. A2, second column). In this case, it seems that the interaction between public employment and level of education captures, at least partly, the magnitude of the association for $\mathrm{P} 1+$ and $\mathrm{P} 2+$. One interpretation of this empirical evidence is that countries worth a high level of gender egalitarianism are those where the proportion of public sector jobs is high and where female full-time employment rates converge with that of men. Under certain condition, this could generate pressure on male partners to adapt to the women's new role (Esping-Andersen, 2016, p. 46). Moreover, countries where public sector jobs are more widespread are those where higher educated women are more likely to be employed as public servants (in semi-qualified jobs), compared to their less-educated counterpart. This seems to suggest that controlling for the interaction between public employment and education, the second portion of the U-shaped relationship between gender egalitarianism and $\mathrm{P} 1+$ and $\mathrm{P} 2+$ for high-educated individuals is partly captured by the interaction.

Another robustness check that we implement is related to a possible limitation deriving from the fact that our models do not include all contextual variables in a single model. In order to verify the robustness of our results when all contextual factors of interest are controlled for, we present estimates for the interaction between education and gender egalitarianism (and its square), where level of part-time employment, level of public employment, EPL and level of post modernism are controlled (all together). Model 5 confirms that the educational gradient is moderated by the level of gender egalitarianism in a manner that is consistent with results reported in the main text (see also the fifth column of Fig. A2).

We also implemented an additional robustness check. Given the issue of unobserved heterogeneity that upsurged in considering $\mathrm{P} 2+$ and $\mathrm{P} 3+$, we estimate all the regression models using the total number of children as the dependent variable. Since this is a count variable, we employed a multilevel Poisson's regression model (e.g. Baizan et al. 2016). According to the results reported in Table A5 and Fig. A3, the level of availability of part-time employment seems to decrease the educational gradient throughout a reduction of the fertility of low-educated women, as observed for P1 + in the main models. The findings also suggest that, as in the main analyses on parities, the educational gradient is not strictly influenced by availability of public employment or by the strictness of EPL. Results about part-time availability are also robust when we delate from the analysis the countries with the extreme values of part-time availability. See Table A7.

Finally, analyses on the educational gradient of completed fertility confirm that both a high level of post-modernism and a high diffusion of gender egalitarianism are associated with a reduction of the educational gap.

\section{Conclusions}

The negative association between women's educational attainment and fertility, essentially, has always been an uncontested statement in

\footnotetext{
${ }^{28}$ Specifically, we calculated the mean of gender egalitarianism within country considering the two periods and then we subtracted to each value of gender egalitarianism (one for period) the mean of the variable.
} 
social sciences. However, recent contributions have shown a reverse in the educational gradient in some European countries but not in others.

In seeking to address this issue, our study has extensively examined the interplay between structural and cultural factors. As previous literature has shown, their contribution is crucial to the regulation of economic and social relations within families and to the process of social stratification of reproductive choices. Specifically, this article has attempted to widen the conventional perspective of the societal determinants of the educational gradient of fertility, in two ways. First of all, we have gained more knowledge about the role played by structural and ideational conditions that sociological and demographic research only partially analysed. Second, we have expanded the theoretical and analytical focus to specific parities.

Theorists of the New Home Economics have traditionally posited that labour market regulation, among other individual institutions, represents a crucial determinant of fertility differentials between educational classes. This is because it alters the opportunity costs of motherhood dissimilarly across educational groups. According to this perspective, a family-friendly labour market setting, decreasing the opportunity costs of childrearing through the promotion of part-time opportunities, the development of the public sector employment and/or the reinforcement of legal restrictions to dismissals, should lead to a reduction of the educational stratification in reproductive behaviour. Our results show instead that, from an associative point of view, it does not systematically alter the gradient. Rather, its influence, depends on the parity progression considered.

More specifically, our findings imply a discrepancy between the conventional belief that part-time opportunities are positively related to childbearing and, on the other hand, evidence that highly educated women are more likely to forgo motherhood in case of high availability of part-time jobs. Moreover, this study challenges the assertion that policies aimed at reducing work-family incompatibility through a strict regulation of employment contracts are suitable to narrow fertility educational differentials. We find, instead, that rigid labour markets, that mainly privilege middle-aged male workers, not only are associated with a steeper educational gradient of childlessness but also have a negative relationship with each specific parity progression.

Nevertheless, we observe that where labour market regulation is oriented to women's empowerment through the promotion of stable and (semi)professional careers in the public sector, an overall increase in parity progression and a reduction of the educational gap in childlessness are found.

In short, within its theoretical framework, the New Economics framework should embody the contributions of an emerging literature that - together with this study - assesses that the role of women's education would become weaker where labour markets are converted into more oriented to favouring long-term careers for mothers (and more prompted to endorse their working opportunities). Thus, it appears that the explanation of the heterogeneity of the educational gradient in reproductive behaviour is not just a matter of a "crude" calculus of the opportunity costs. Instead it should embrace a deep reconsideration of more nuanced mechanisms related to women's autonomy and empowerment in different phases of their reproductive life stage.

In this regard, a number of studies have highlighted that a more crucial factor is represented by a progressive reconfiguration of family ideals and, in particular, by the degree of rejection of traditional standards in the individuals' private sphere. Even if not exerting a direct influence on the opportunity costs of motherhood, these elements culturally affect family-life preferences and shape perceptions of incompatibility of woman's responsibilities as mother and worker. While the post-modernist variant of the SDT theory mainly interprets the discharge of traditionalism as an opposition to religious beliefs about family ideals, the Multiple Equilibrium paradigm identifies it as a gender role reconfiguration about who is the appropriate breadwinner.

From our results it appears that a widespread religious secularization, that is strongly associated with abandoning the ideal type of traditional family, actually constitutes a cultural aspect that may lead to a decrease of the steepness of the educational gradient of fertility by parity.
However, there is little evidence that higher-educated women are influenced by the diffusion of these new values regarding their reproductive choices. Instead the mechanism at play here is mostly associated with a depression of fertility of lower educated women. In fact, we observe that in more individualistic societies they represent the most disadvantageous educational group in terms of fertility progressions.

Thus, from our empirical analysis, the indication that higher educated women, identified as the avant-garde clientele of post-modernism, are not appreciably responsive, in their reproductive choices, to the degree of acceptance of post-modernist attitudes partly undermines the predictions of the theory. Our findings seem to suggest that the postmodernist variant of SDT, considering less-family preferences (as childlessness acceptance) as the sole results of the rejection of traditional values, goes too far in assuming the impossibility of a reconciliation between anti-conservative family attitudes and pro-family behaviours. What this theory seems to miss is interpreting the diffusion of postmodernist attitudes as compatible with the spread of other cultural forces related to new forms of pro-family orientations. Indeed, an explanation incorporating the emerging of new gender values as the other face of the disruption of traditional family ideals should better account for the reproductive choices of highly educated women. This argument suggests that attitudinal orientations that, adhering to an unconventional new family model (complying with gender empowerment), can better predict the reproductive behaviour of women with college education.

In line with this argument, we find that, in societies with a broad diffusion of gender egalitarian attitudes, the educational gradient is narrow. Given that highly-educated women are more career committed and are more likely to command economic resources, they seem inclined toward having babies only if their partner adheres to gender-egalitarian principles (and this is the case where acceptance of gender egalitarianism is almost universal). In this sense, the costs of motherhood appear strongly reduced where fathers are more oriented to socializing the costs of domestic duties. Instead, within those societies where traditional gender values have waned but gender egalitarianism remains poorly diffused, the odds of being childless or having small families peak for highly educated women. Thus, it does seem that egalitarian gender values, enhancing the participation of men in domestic and caring duties, can neutralize fertility disadvantages of higher educated women. The general implication of our findings is that the diffusion of egalitarian norms could represent a resource to establish a new equilibrium characterised by smaller educational gaps in reproductive behaviour and a general higher level of fertility, for both high and low educated women.

Our study is subject to main limitations that imply being cautious in interpreting our results as definitive evidence. First of all, this study is limited by the cross-sectional design. Even if this approach is widely employed because it allows for comparative analysis across a large number of countries, it limits our capacity to draw causal results. However, to date, no longitudinal data exist on completed fertility in numerous European regions - even if Kolk (2019) goes in this direction. Another caveat relates to the bias in sorting groups into educational classes - given that the selectivity into educational tracks differs across countries. A possible extension of this article should consider the relative approach to education thus making human capital more comparable across countries. Third, our regression results may suffer of endogeneity bias. More specifically, the women who constitute the sample at risk of having a second or third child may represent a group with unobservable characteristics that are not common among childless women. Thus, our findings may be driven by the selected nature of the groups. Future research should detect whether these selection processes biased our results. Fourth, given the limitation of the available data, we are not able to consider a relevant contextual factor that partly drives the fertility decisions of higher educated women, that is childcare services for children aged 0-2 (Bavel \& Różańska-Putek, 2010). In parallel, future contributions, given the increasingly availability of data on attitudes, would enrich our empirical results implementing a more refined index of postmodernism. A final concern of our study is that we are not able to consider all the indicators of interest and the interaction with educational level at 
once. For this reason, future studies should develop an integrated model of structural and cultural characteristics through a composite indicator that allows for their quantitative assessment. Doing that, one could also consider contextual factors that have been overlooked in this study, such as more refined indicators of family policies, but also political factors that are likely to shape fertility decisions (for a review see Balbo, Billari, \& Mills, 2013).

\section{Acknowledgments}

This research was supported by Gøsta Esping Andersen's European Research Council Advanced Grant FP7-IDEAS-ERC/269387 ('Family Polarization'). The author would like to thank Gøsta Esping-Andersen, Tomas Sobotka and Aart Liefbroer for their inputs and useful comments.

\section{Appendix A}
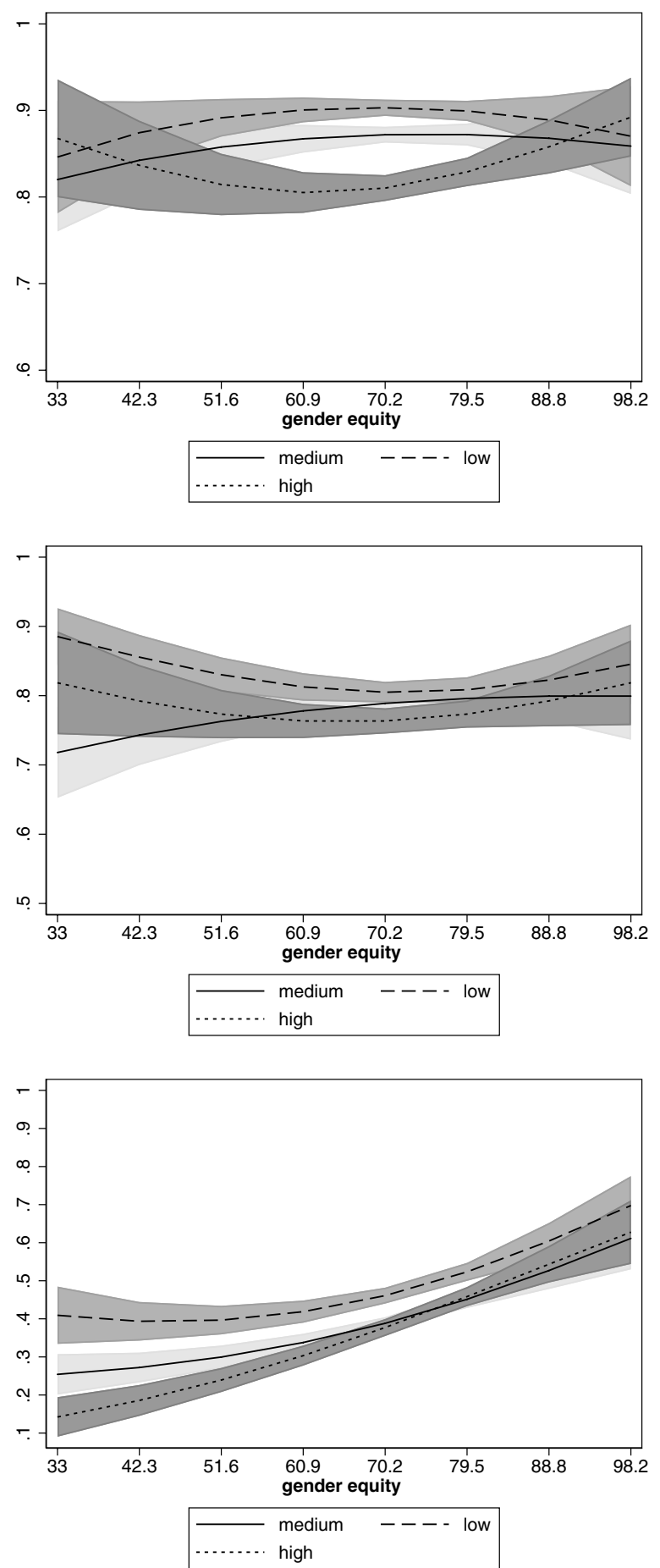

Fig. A1. Predicted probabilities of having at least one, two or three children with $95 \%$ confidence level intervals for pair-wise comparison, within component. 

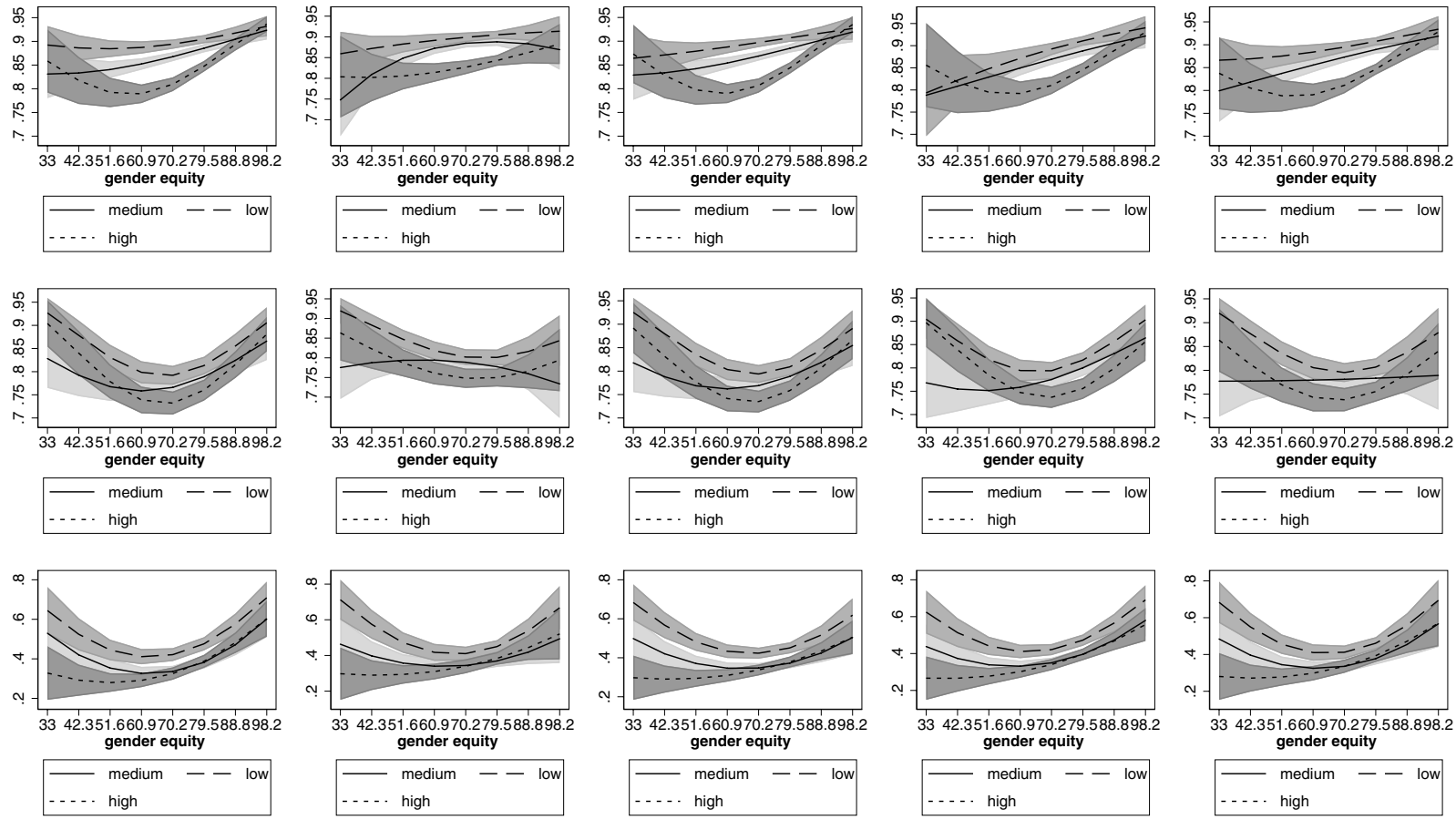

Fig. A2. Predicted probabilities of having at least one (first row), two (second row) or three (third row) children by country level's gender equity with $95 \%$ confidence level intervals for pair-wise comparison.

Note. First column includes interaction between part time and level of education. Second column includes interaction between public employment and level of education. Third column includes interaction between EPL and level of education. Fourth column includes interaction between post modernism and level of education. Last column includes also controls for part-time, public-employment, EPL and post modernism.
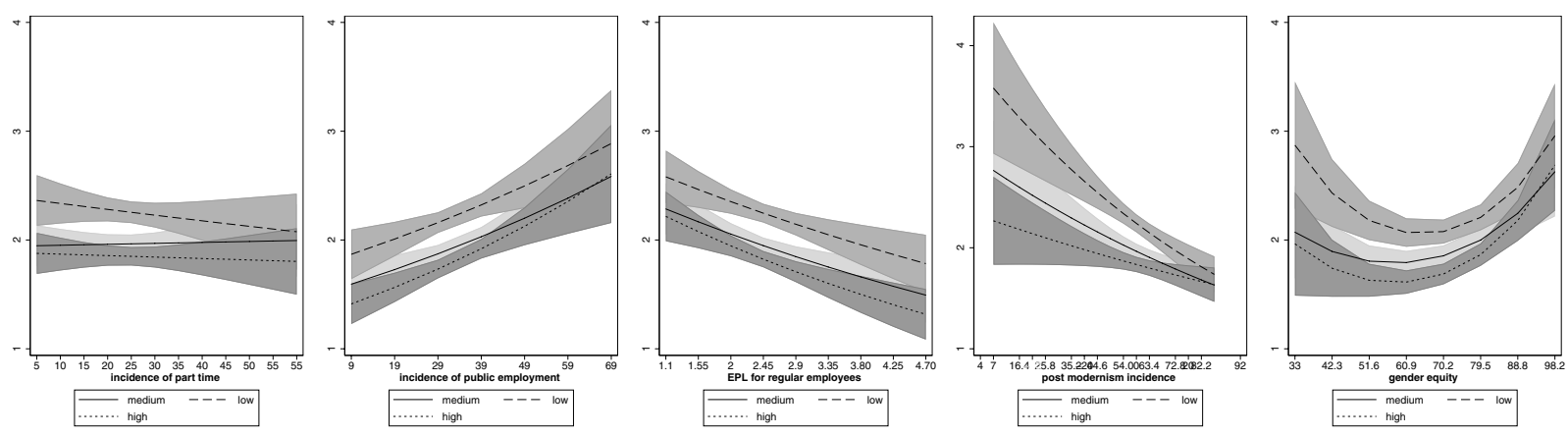

Fig. A3. Predicted number of children by country level's variable with $95 \%$ confidence level intervals for pair-wise comparison. 

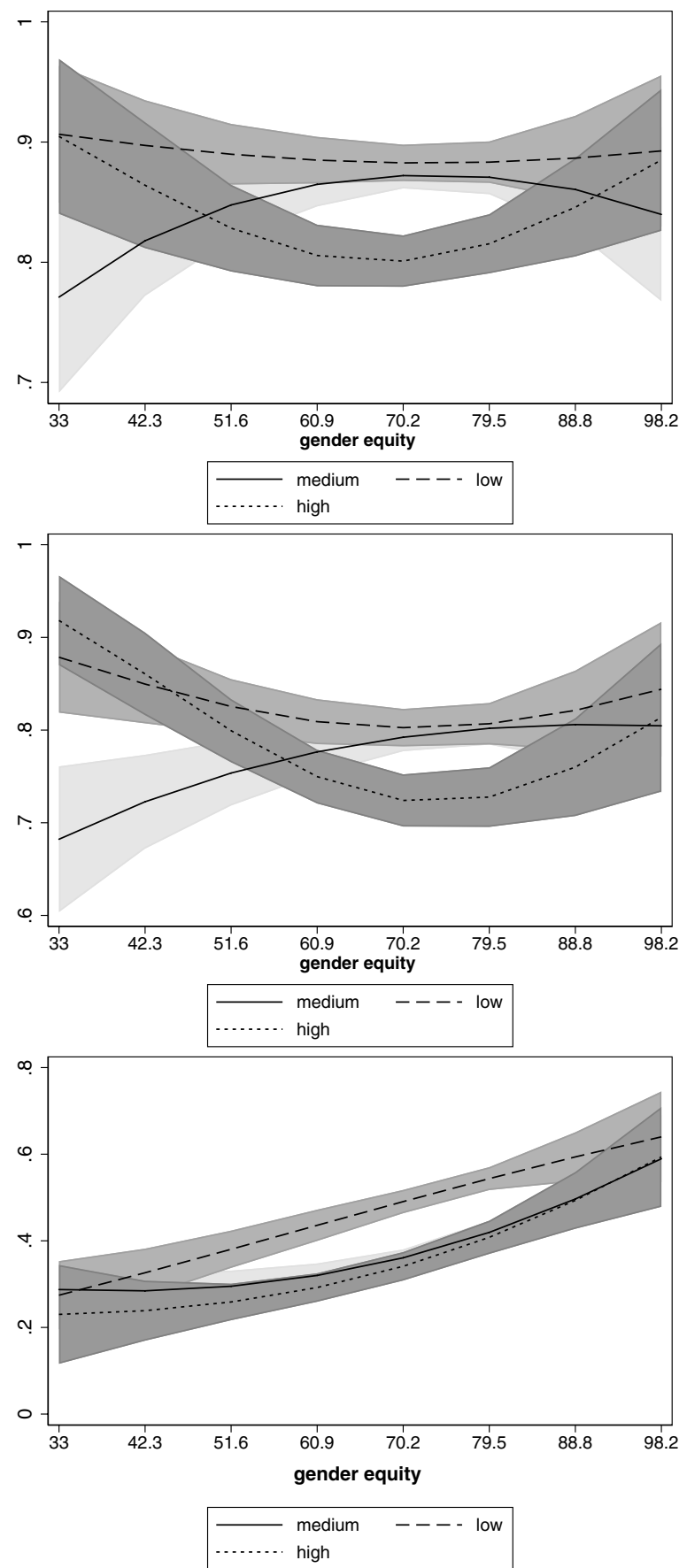

Fig. A4. Predicted probabilities of having at least one, two or three children with $95 \%$ confidence level intervals for pair-wise comparison, including countryeducation fixed effects. 
Table A1

Structure of the data: women by birth-cohorts and countries, pooled dataset, initial sample.

\begin{tabular}{llll}
\hline Country & cohort 1 & cohort 2 & Total \\
\hline & No. & No. & No. \\
AT & 322 & 566 & 888 \\
BE & 332 & 364 & 696 \\
CH & 379 & 439 & 818 \\
CZ & 323 & 247 & 570 \\
DE & 591 & 704 & 1295 \\
DK & 290 & 300 & 590 \\
EE & & 354 & 354 \\
ES & 293 & 397 & 690 \\
FI & 374 & 359 & 733 \\
FR & 390 & 403 & 793 \\
GB & 304 & 358 & 662 \\
GR & 236 & 252 & 488 \\
HU & & 313 & 313 \\
IE & 337 & 322 & 659 \\
IS & 84 & 104 & 188 \\
LU & 154 & 199 & 353 \\
NL & 438 & 440 & 878 \\
NO & 341 & 376 & 717 \\
PL & 436 & 370 & 806 \\
PT & 375 & 351 & 726 \\
SE & 380 & 366 & 746 \\
SI & 346 & 363 & 363 \\
SK & 393 & 313 & 659 \\
TR & & 338 & 595 \\
Total & 257 & 8598 & 15580 \\
\hline & & &
\end{tabular}




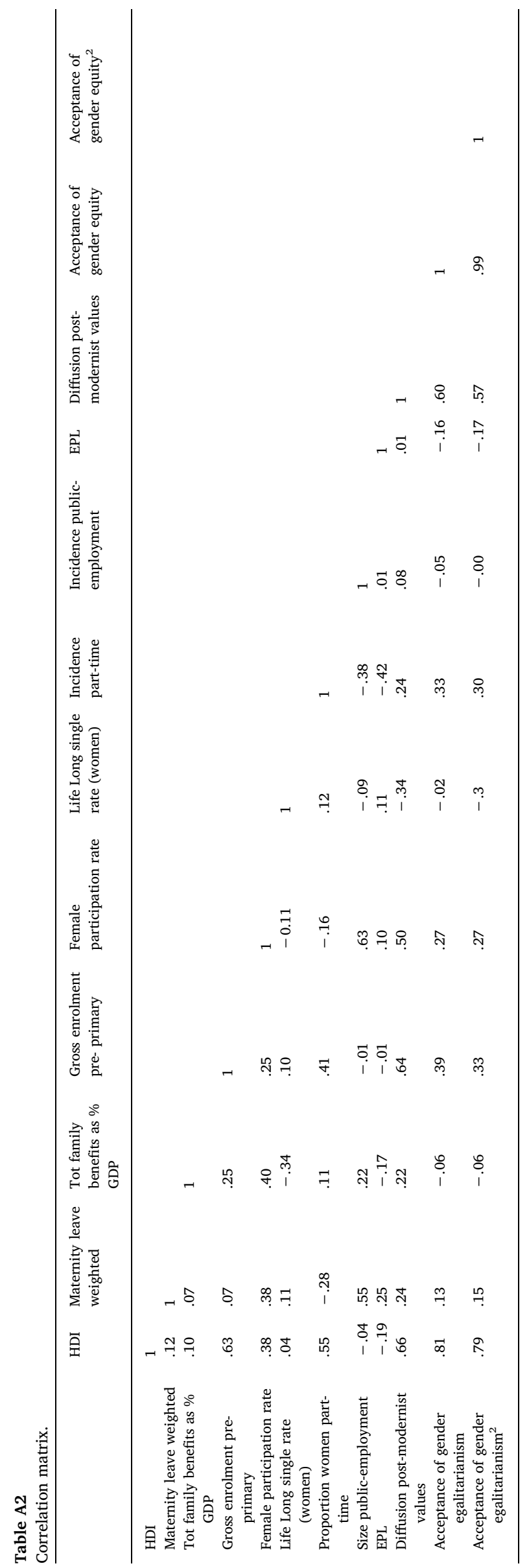


Table A3

Results of Multilevel logistic regression on having at least one child, two and three children on individual characteristics and country fixed effects and egalitarianism. Odds ratios.

\begin{tabular}{llll}
\hline & Model 1 & Model 2 & Model 3 \\
\hline Age & 1.008 & 0.996 & 1.001 \\
& $(0.012)$ & $(0.011)$ & $(0.010)$ \\
Cohort & 1.053 & 0.864 & $.708^{* * *}$ \\
& $(0.140)$ & $(0.099)$ & $(0.076)$ \\
Dataset: ESS (ref.) & & & 0.943 \\
EVS & $1.143^{* *}$ & $1.118^{*}$ & $(0.054)$ \\
& $(0.080)$ & $(0.070)$ & 0.920 \\
WVS & $1.359^{* * *}$ & 1.027 & $(0.069)$ \\
Educational level: medium (ref.) & $(0.132)$ & $(0.086)$ & $1.375^{* * *}$ \\
Low & & & $(0.103)$ \\
& $1.375^{* * *}$ & 0.951 \\
High & $(0.125)$ & 1.107 & $(0.077)$ \\
Gender egalitarianism & $0.621^{* * *}$ & $(0.089)$ & $1.026^{* * *}$ \\
& $(0.050)$ & $0.861^{*}$ & $(0.007)$ \\
*low education & 1.002 & $(0.070)$ & 0.997 \\
& $(0.008)$ & 1.005 & $(0.004)$ \\
*high education & 0.997 & $(0.007)$ & $1.010^{* * *}$ \\
Gender egalitarianism ${ }^{* *}$ & $(0.005)$ & 0.993 & $(0.004)$ \\
& 1.006 & $(0.004)$ & 1.000 \\
*low education & $(0.005)$ & 0.997 & $(0.000)$ \\
& 1.000 & $(0.004)$ & 1.000 \\
*high education & $(0.000)$ & 1.000 & $(0.000)$ \\
Country fixed effects & 1.000 & $(0.000)$ & 1.000 \\
Observations & $(0.000)$ & $1.000^{* *}$ & $(0.000)$ \\
Number of groups & $1.001^{* * *}$ & $(0.000)$ & YES \\
\hline
\end{tabular}

Note: ${ }^{* * *} \mathrm{p}<0.01, * * \mathrm{p}<0.05,{ }^{*} \mathrm{p}<0.1$ 


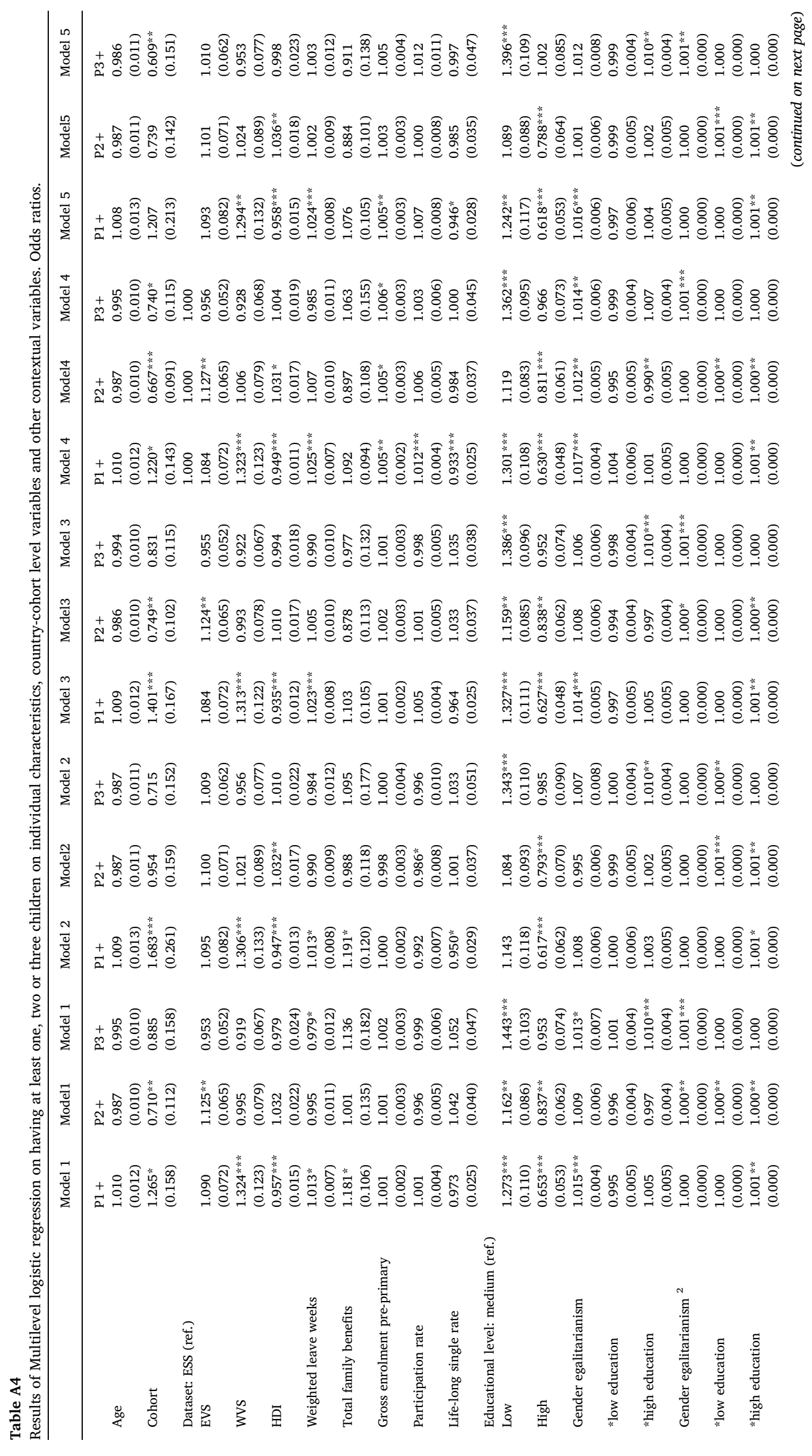




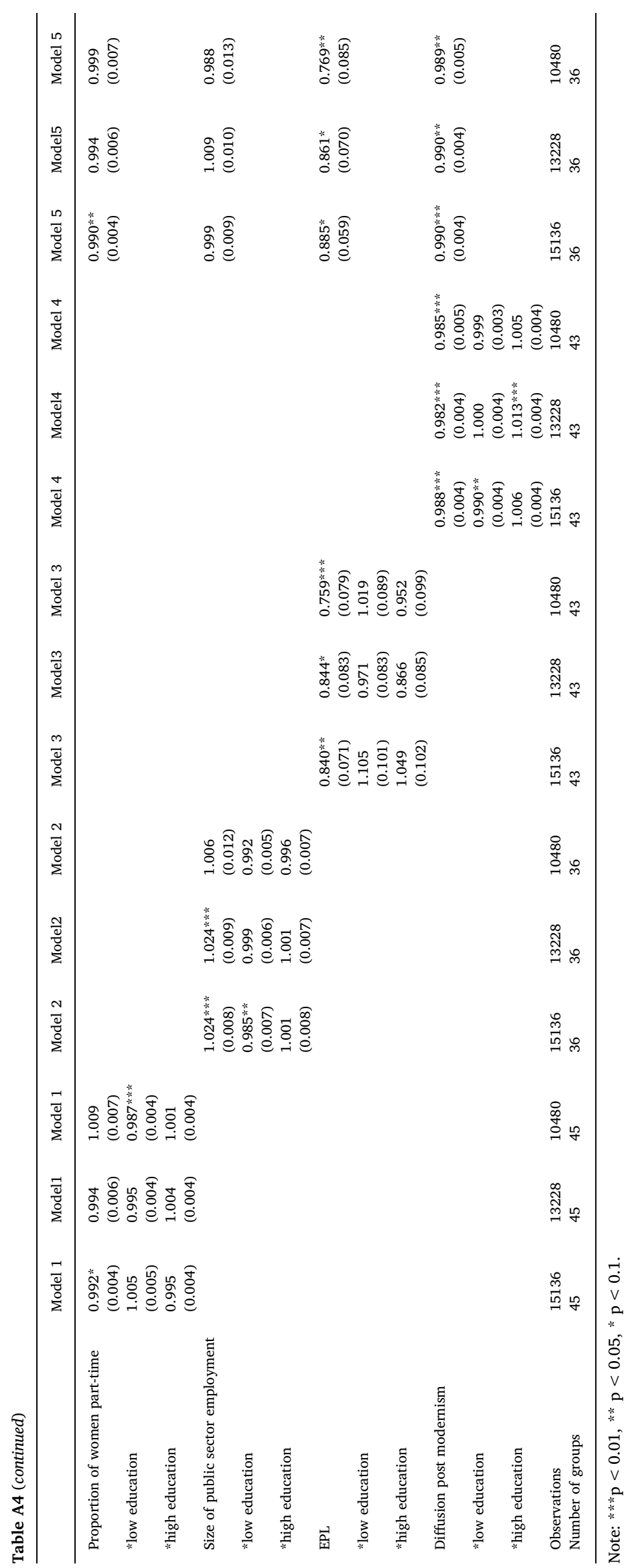


Table A5

Estimates of a series of two-level Poisson's regression models for completed fertility on individual characteristics and country-cohort level variables interactions.

\begin{tabular}{|c|c|c|c|c|c|}
\hline Number of children & Model 1 & Model 2 & Model 3 & Model 4 & Model 5 \\
\hline Age & $\begin{array}{l}0.999 \\
(0.003)\end{array}$ & $\begin{array}{l}0.998 \\
(0.003)\end{array}$ & $\begin{array}{l}0.999 \\
(0.003)\end{array}$ & $\begin{array}{l}0.999 \\
(0.003)\end{array}$ & $\begin{array}{l}0.999 \\
(0.003)\end{array}$ \\
\hline Cohort & $\begin{array}{l}1.017 \\
(0.058)\end{array}$ & $\begin{array}{l}1.114^{* *} \\
(0.059)\end{array}$ & $\begin{array}{l}1.025 \\
(0.047)\end{array}$ & $\begin{array}{l}0.957 \\
(0.046)\end{array}$ & $\begin{array}{l}1.006 \\
(0.046)\end{array}$ \\
\hline Dataset: ESS (ref.) & 1.000 & 1.000 & 1.000 & 1.000 & 1.000 \\
\hline EVS & $\begin{array}{l}1.022 \\
(0.015)\end{array}$ & $\begin{array}{l}1.025 \\
(0.017)\end{array}$ & $\begin{array}{l}1.021 \\
(0.015)\end{array}$ & $\begin{array}{l}1.025 * \\
(0.016)\end{array}$ & $\begin{array}{l}1.025 \\
(0.016)\end{array}$ \\
\hline WVS & $\begin{array}{l}1.011 \\
(0.021)\end{array}$ & $\begin{array}{l}1.018 \\
(0.023)\end{array}$ & $\begin{array}{l}1.010 \\
(0.021)\end{array}$ & $\begin{array}{l}1.011 \\
(0.021)\end{array}$ & $\begin{array}{l}1.011 \\
(0.021)\end{array}$ \\
\hline HDI & $\begin{array}{l}0.997 \\
(0.007)\end{array}$ & $\begin{array}{l}0.995 \\
(0.004)\end{array}$ & $\begin{array}{l}0.992^{*} \\
(0.004)\end{array}$ & $\begin{array}{l}1.005 \\
(0.005)\end{array}$ & $\begin{array}{l}0.990 * \\
(0.006)\end{array}$ \\
\hline Weighted leave weeks & $\begin{array}{l}0.998 \\
(0.004)\end{array}$ & $\begin{array}{l}0.997 \\
(0.003)\end{array}$ & $\begin{array}{l}1.004 \\
(0.004)\end{array}$ & $\begin{array}{l}1.003 \\
(0.004)\end{array}$ & $\begin{array}{l}0.998 \\
(0.003)\end{array}$ \\
\hline Total family benefits & $\begin{array}{l}1.016 \\
(0.053)\end{array}$ & $\begin{array}{l}1.031 \\
(0.046)\end{array}$ & $\begin{array}{l}0.969 \\
(0.043)\end{array}$ & $\begin{array}{l}0.971 \\
(0.043)\end{array}$ & $\begin{array}{l}1.039 \\
(0.046)\end{array}$ \\
\hline Enrolment pre-primary & $\begin{array}{l}1.000 \\
(0.001)\end{array}$ & $\begin{array}{l}0.999 \\
(0.001)\end{array}$ & $\begin{array}{l}1.000 \\
(0.001)\end{array}$ & $\begin{array}{l}1.001 \\
(0.001)\end{array}$ & $\begin{array}{l}1.001 \\
(0.001)\end{array}$ \\
\hline Participation rate & $\begin{array}{l}1.000 \\
(0.002)\end{array}$ & $\begin{array}{l}0.995^{* *} \\
(0.002)\end{array}$ & $\begin{array}{l}1.000 \\
(0.002)\end{array}$ & $\begin{array}{l}1.003 \\
(0.002)\end{array}$ & $\begin{array}{l}1.000 \\
(0.002)\end{array}$ \\
\hline Life-long single rate & $\begin{array}{l}0.989 \\
(0.013)\end{array}$ & $\begin{array}{l}0.989 \\
(0.011)\end{array}$ & $\begin{array}{l}0.987 \\
(0.011)\end{array}$ & $\begin{array}{l}0.966^{* * *} \\
(0.012)\end{array}$ & $\begin{array}{l}1.015 \\
(0.013)\end{array}$ \\
\hline $\begin{array}{r}\text { Educational level: } \\
\text { medium (ref.) }\end{array}$ & 1.000 & 1.000 & 1.000 & 1.000 & 1.000 \\
\hline Low & $\begin{array}{l}1.147^{* * *} \\
(0.017)\end{array}$ & $\begin{array}{l}1.148^{* * *} \\
(0.019)\end{array}$ & $\begin{array}{l}1.153^{* * *} \\
(0.017)\end{array}$ & $\begin{array}{l}1.141^{* * *} \\
(0.017)\end{array}$ & $\begin{array}{l}1.120 * * * \\
(0.022)\end{array}$ \\
\hline High & $\begin{array}{l}0.942^{* * *} \\
(0.014)\end{array}$ & $\begin{array}{l}0.935^{* * *} \\
(0.016)\end{array}$ & $\begin{array}{l}0.936^{* * *} \\
(0.015)\end{array}$ & $\begin{array}{l}0.934 * * * \\
(0.015)\end{array}$ & $\begin{array}{l}0.910 * * * \\
(0.019)\end{array}$ \\
\hline $\begin{array}{l}\text { Proportion of women } \\
\text { part-time }\end{array}$ & $\begin{array}{l}1.000 \\
(0.002)\end{array}$ & & & & \\
\hline *low education & $\begin{array}{l}0.997^{* * *} \\
(0.001)\end{array}$ & & & & \\
\hline *high education & $\begin{array}{l}0.999 \\
(0.001)\end{array}$ & & & & \\
\hline $\begin{array}{l}\text { Size of public sector } \\
\text { employment }\end{array}$ & & $\begin{array}{l}1.008^{* * *} \\
(0.002)\end{array}$ & & & \\
\hline *low education & & $\begin{array}{l}0.999 \\
(0.001)\end{array}$ & & & \\
\hline *high education & & $\begin{array}{l}1.002 \\
(0.001)\end{array}$ & & & \\
\hline EPL & & & $\begin{array}{l}0.899 * * * \\
(0.030)\end{array}$ & & \\
\hline *low education & & & $\begin{array}{l}1.014 \\
(0.024)\end{array}$ & & \\
\hline *high education & & & $\begin{array}{l}0.977 \\
(0.027)\end{array}$ & & \\
\hline $\begin{array}{l}\text { Diffusion post } \\
\text { modernism }\end{array}$ & & & & $\begin{array}{l}0.994^{* * *} \\
(0.002)\end{array}$ & \\
\hline *low education & & & & $\begin{array}{l}0.998^{* * *} \\
(0.001)\end{array}$ & \\
\hline *high education & & & & $\begin{array}{l}1.002^{* * *} \\
(0.001)\end{array}$ & \\
\hline Gender egalitarianism & & & & & $\begin{array}{l}1.005^{* * *} \\
(0.002)\end{array}$ \\
\hline *low education & & & & & $\begin{array}{l}0.998 * * \\
(0.001)\end{array}$ \\
\hline *high education & & & & & $\begin{array}{l}1.002^{*} \\
(0.001)\end{array}$ \\
\hline Gender egalitarianism $^{2}$ & & & & & $\begin{array}{l}1.000 * * * \\
(0.000)\end{array}$ \\
\hline *low education & & & & & $\begin{array}{l}1.000 * \\
(0.000)\end{array}$ \\
\hline *high education & & & & & $\begin{array}{l}1.000 \\
(0.000)\end{array}$ \\
\hline Observations & 15568 & 12414 & 15333 & 15179 & 15179 \\
\hline Number of groups & 45 & 36 & 43 & 43 & 43 \\
\hline
\end{tabular}

Note: $* * * \mathrm{p}<0.01, * * \mathrm{p}<0.05, * \mathrm{p}<0.1$. 
Table A6

Results of Multilevel logistic regression on having at least one child, two and three children on individual characteristics, including country-education fixed effects and egalitarianism. Odds ratios.

\begin{tabular}{|c|c|c|c|}
\hline & Model 1 & Model 2 & Model 3 \\
\hline Age & $\begin{array}{l}1.008 \\
(0.012)\end{array}$ & $\begin{array}{l}0.987 \\
(0.011)\end{array}$ & $\begin{array}{l}1.002 \\
(0.010)\end{array}$ \\
\hline Cohort & $\begin{array}{l}1.055 \\
(0.141)\end{array}$ & $\begin{array}{l}0.872 \\
(0.102)\end{array}$ & $\begin{array}{l}0.745^{* * * *} \\
(0.082)\end{array}$ \\
\hline \multicolumn{4}{|l|}{ Dataset: ESS (ref.) } \\
\hline EVS & $\begin{array}{l}1.155^{* * *} \\
(0.081)\end{array}$ & $\begin{array}{l}1.112^{*} \\
(0.070)\end{array}$ & $\begin{array}{l}0.951 \\
(0.055)\end{array}$ \\
\hline wVS & $\begin{array}{l}1.410^{* * * *} \\
(0.139)\end{array}$ & $\begin{array}{l}1.010 \\
(0.085)\end{array}$ & $\begin{array}{l}0.922 \\
(0.070)\end{array}$ \\
\hline Gender egalitarianism & $\begin{array}{l}1.003 \\
(0.009)\end{array}$ & $\begin{array}{l}1.008 \\
(0.008)\end{array}$ & $\begin{array}{l}1.023^{* * * *} \\
(0.008)\end{array}$ \\
\hline *low education & $\begin{array}{l}0.997 \\
(0.010)\end{array}$ & $\begin{array}{l}0.991 \\
(0.009)\end{array}$ & $\begin{array}{l}1.001 \\
(0.008)\end{array}$ \\
\hline *high education & $\begin{array}{l}1.001 \\
(0.009)\end{array}$ & $\begin{array}{l}0.986 \\
(0.009)\end{array}$ & $\begin{array}{l}1.004 \\
(0.009)\end{array}$ \\
\hline Gender egalitarianism $^{2}$ & $\begin{array}{l}1.000 \\
(0.000)\end{array}$ & $\begin{array}{l}1.000 \\
(0.000)\end{array}$ & $\begin{array}{l}1.000^{*} \\
(0.000)\end{array}$ \\
\hline *low education & $\begin{array}{l}1.001 \\
(0.000)\end{array}$ & $\begin{array}{l}1.001 \\
(0.000)\end{array}$ & $\begin{array}{l}1.000 \\
(0.000)\end{array}$ \\
\hline *high education & $\begin{array}{l}1.001^{* *} \\
(0.000)\end{array}$ & $\begin{array}{l}1.001^{* *} \\
(0.000)\end{array}$ & $\begin{array}{l}1.000 \\
(0.000)\end{array}$ \\
\hline Country fixed effects & YES & YES & YES \\
\hline Country*education fixed effects & YES & YES & YES \\
\hline Observations & 13472 & 11710 & 9297 \\
\hline Number of groups & 36 & 36 & 36 \\
\hline
\end{tabular}

Note: $* * \mathrm{p}<0.01, * * \mathrm{p}<0.05,{ }^{*} \mathrm{p}<0.1$

Table A7

Exclusion of NL or CH from model on part-time availability. Odds Ratios.

\begin{tabular}{|c|c|c|c|c|c|c|}
\hline & Model 1 & Model 2 & Model 3 & Model 4 & Model 5 & Model 6 \\
\hline \multirow[t]{2}{*}{ Age } & 1.015 & 0.986 & 0.998 & 1.015 & 0.985 & 0.996 \\
\hline & $(0.012)$ & $(0.010)$ & $(0.010)$ & $(0.012)$ & $(0.010)$ & $(0.010)$ \\
\hline \multirow[t]{2}{*}{ Cohort } & 1.230 & 0.781 & 1.037 & $1.252^{*}$ & 0.803 & 1.011 \\
\hline & $(0.174)$ & $(0.138)$ & $(0.215)$ & $(0.164)$ & $(0.142)$ & $(0.210)$ \\
\hline \multicolumn{7}{|l|}{ Dataset: ESS (ref.) } \\
\hline \multirow[t]{2}{*}{ EVS } & 1.074 & 1.086 & 0.933 & 1.080 & $1.115^{*}$ & 0.921 \\
\hline & $(0.073)$ & $(0.063)$ & $(0.052)$ & $(0.074)$ & $(0.065)$ & $(0.051)$ \\
\hline \multirow[t]{2}{*}{ WVS } & $1.258^{* *}$ & 0.989 & $0.873^{*}$ & $1.302 * *$ & 0.990 & 0.916 \\
\hline & $(0.124)$ & $(0.081)$ & $(0.067)$ & $(0.135)$ & $(0.082)$ & $(0.070)$ \\
\hline \multicolumn{7}{|c|}{ Educational level: medium (ref.) } \\
\hline \multirow[t]{2}{*}{ Low } & $1.331 * * *$ & $1.342^{* * *}$ & $1.602^{* * *}$ & $1.289 * * *$ & $1.341^{* * *}$ & $1.555^{* * *}$ \\
\hline & $(0.095)$ & $(0.080)$ & $(0.087)$ & $(0.091)$ & $(0.079)$ & $(0.084)$ \\
\hline \multirow[t]{2}{*}{ High } & $0.772 * * *$ & 0.949 & 0.936 & $0.764 * * *$ & 0.951 & 0.920 \\
\hline & $(0.051)$ & $(0.055)$ & $(0.054)$ & $(0.050)$ & $(0.055)$ & $(0.053)$ \\
\hline \multirow[t]{2}{*}{ Part time } & $0.989^{*}$ & 0.994 & 1.016 & 0.995 & 0.999 & $1.016^{*}$ \\
\hline & $(0.006)$ & $(0.008)$ & $(0.010)$ & $(0.005)$ & $(0.007)$ & $(0.008)$ \\
\hline \multirow[t]{2}{*}{ *low education } & 1.001 & $0.991 * *$ & $0.989 * *$ & 0.998 & $0.992 * *$ & $0.985^{* * *}$ \\
\hline & $(0.005)$ & $(0.005)$ & $(0.004)$ & $(0.005)$ & $(0.004)$ & $(0.004)$ \\
\hline \multirow[t]{2}{*}{ *high education } & 0.998 & 1.007 & $1.013^{* * *}$ & 0.994 & 1.004 & 1.004 \\
\hline & $(0.005)$ & $(0.004)$ & $(0.005)$ & $(0.004)$ & $(0.004)$ & $(0.004)$ \\
\hline Country excluded & NL & NL & NL & $\mathrm{CH}$ & $\mathrm{CH}$ & $\mathrm{CH}$ \\
\hline Observations & 14649 & 12832 & 10128 & 14706 & 12925 & 10226 \\
\hline Number of groups & 43 & 43 & 43 & 43 & 43 & 43 \\
\hline
\end{tabular}

Note: ${ }^{* * *} \mathrm{p}<0.01,{ }^{* *} \mathrm{p}<0.05,{ }^{*} \mathrm{p}<0.1$; we control for all the aggregate variables as in previous models.

\section{References}

Aassve, A., Sironi, M., \& Bassi, V. (2011). Explaining attitudes towards demographic behaviour. European Sociological Review, 29(2), 316-333.

Adsera, A. (2004). Changing fertility rates in developed countries. The impact of labor market institutions. Journal of Population Economics, 17(1), 17-43.

Adsera, A. (2005). Vanishing children: From high unemployment to low fertility in developed countries. The American Economic Review, 95(2), 189-193.

Adsera, A. (2011a). Where are the babies? Labor market conditions and fertility in Europe. European Journal of Population, 27(1), 1-32.

Adsera, A. (2011b). The interplay of employment uncertainty and education in explaining second births in Europe. Demographic Research, 25(16), 513.
Andersson, G., Rønsen, M., Knudsen, L. B., Lappegård, T., Neyer, G., Skrede, K., Teschner, K., \& Vikat, A. (2008). Cohort fertility patterns in the Nordic countries. Demographic Research, 20(14), 313-352.

Arpino, B., Esping-Andersen, G., \& Pessin, L. (2015). How do changes in gender role attitudes towards female employment influence fertility? A macro-level analysis. European Sociological Review, 31(3), 370-382.

Baizán, P. (2007). The impact of labour market status on second and higher-order births Family formation and family dilemmas in contemporary Europe, 93-127.

Baizán, P., Arpino, B., \& Delclós, C. E. (2016). The effect of gender policies on fertility: The moderating role of education and normative context. European Journal of Population, 32(1), 1-30.

Balbo, N., Billari, F. C., \& Mills, M. (2013). Fertility in advanced societies: A review of research. European Journal of Population/Revue européenne de Démographie, 29(1), 
$1-38$.

Barakat, B., \& Durham, R. (2013). Drop-out mayors and graduate farmers: Educational fertility differentials by occupational status and industry in six European countries. Demographic Research, 28, 1213-1262.

Bavel, J. V., \& Różańska-Putek, J. (2010). Second birth rates across Europe: Interactions between women's level of education and child care enrolment. Vienna Yearbook of Population Research, 107-138.

Becker, G. (1981). A treatise on the family. Cambridge, Mass: Harvard University Press.

Begall, K., \& Mills, M. (2011). The impact of subjective work control, job strain and work-Family conflict on fertility intentions: A European comparison. European Journal of Population, 27(4), 433.

Begall, K., \& Mills, M. C. (2013). The Influence of educational field, occupation, and occupational sex segregation on fertility in the Netherlands. European Sociological Review, 29(4), 720-742.

Bellani, D., \& Bosio, G. (2019). Knockin' on heaven's door? Reframing the debate on temporary employment and wages: evidence from Europe. Socio-Economic Review. https://doi.org/10.1093/ser/mwz042 forthcoming.

Bellani, D., Esping-Andersen, G., \& Nedoluzhko, L. (2017). Never partnered: A multilevel analysis of lifelong singlehood. Demographic Research, 37, 53-100.

Bianchi, S. M., Casper, L. M., \& Peltola, P. K. (1999). A cross-national look at married women's earnings dependency. Gender Issues, 17(3), 3-33.

Billari, F., \& Kohler, H. P. (2004). Patterns of low and lowest-low fertility in Europe. Population Studies, 58(2), 161-176.

Billingsley, S., \& Ferrarini, T. (2014). Family policy and fertility intentions in 21 European countries. Journal of Marriage and the Family, 76(2), 428-445.

Blossfeld, H. P., \& Huinink, J. (1991). Human capital investments or norms of role transition? How women's schooling and career affect the process of family formation. The American Journal of Sociology, 97(1), 143-168.

Boeri, T., \& Garibaldi, P. (2007). Two tier reforms of employment protection: A honeymoon effect? The Economic Journal, 117(521), F357-F385.

Brinton, M. C., \& Lee, D. J. (2016). Gender-role ideology, labor market institutions, and post-industrial fertility. Population and Development Review, 42(3), 405-433.

Brons, M. D., Liefbroer, A. C., \& Ganzeboom, H. B. (2017). Parental socio-economic status and first union formation: Can european variation Be explained by the second demographic transition theory? European Sociological Review, 33(6), 809-822.

Casquel, E., \& Cunyat, A. (2005). The welfare costs of business cycles in an economy with nonclearing markets (No. 2005-19)FEDEA.

Charles, M., \& Grusky, D. (2004). Occupational ghettos. Stanford, CA: Stanford University.

Davie, E., \& Mazuy, M. (2010). Women's fertility and educational level in France: Evidence from the annual census surveys. Population, 65(3), 415-450.

Del Boca, D., \& Sauer, R. M. (2009). Life cycle employment and fertility across institutional environments. European Economic Review, 53(3), 274-292.

Del Boca, D., Pasqua, S., \& Pronzato, C. (2006). The impact of institutions on motherhood and work. Institute of Social and Economic Research.

Dieckhoff, M., Gash, V., Mertens, A., \& Gordo, L. R. (2016). A stalled revolution? What can we learn from women's drop-out to part-time jobs: A comparative analysis of Germany and the UK. Research in Social Stratification and Mobility, 46, 129-140.

Dolado, J. J., García-Serrano, C., \& Jimeno, J. F. (2002). Drawing lessons from the boom of temporary jobs in Spain. The Economic Journal, 112(480), F270-F295.

Esping-Andersen, G. (1999). Social foundations of postindustrial economies. Oxford: Oxford University Press.

Esping-Andersen, G. (2009). Incomplete revolution: Adapting welfare states to women's new roles. Cambridge: Polity Press.

Esping-Andersen, G. (2016). Families in the 21st century (p. 113)Stockholm: SNS förlag.

Esping-Andersen, G., \& Billari, F. C. (2015). Re-theorizing family demographics. Population and Development Review, 41(1), 1-31.

Evertsson, M., England, P., Mooi-Reci, I., Hermsen, J., De Bruijn, J., \& Cotter, D. (2009). Is gender inequality greater at lower or higher educational levels? Common patterns in the Netherlands, Sweden, and the United States. Social Politics International Studies in Gender State \& Society.

Fogli, A. (2004). Endogenous labor Market rigidities and family ties'. Working Paper Presented at New York University Stern School of Business.

Freijka, T., \& Sobotka, T. (2008). Fertility in Europe: Diverse, delayed and below replacement. Demographic Research, 19, 15-46.

Gangl, M., \& Ziefle, A. (2009). Motherhood, labor force behavior, and women's careers: An empirical assessment of the wage penalty for motherhood in Britain, Germany, and the United States. Demography, 46(2), 341-369.

Garibaldi, P., \& Violante, G. L. (2005). The employment effects of severance payments with wage rigidities. The Economic Journal, 115(506), 799-832.

Gauthier, A. H. (2007). The impact of family policies on fertility in industrialized countries: A review of the literature. Population Research and Policy Review, 26(3), 323-346.

Gauthier, A. H., \& Hatzius, J. (1997). Family benefits and fertility: An econometric analysis. Population Studies, 51(3), 295-306.

Gebel, M., \& Giesecke, J. (2011). Labor market flexibility and inequality: The changing skill-based temporary employment and unemployment risks in Europe. Social Forces, 90(1), 17-39.

Goldscheider, F., Bernhardt, E., \& Lappegård, T. (2015). The gender revolution: A framework for understanding changing family and demographic behavior. Population and Development Review, 41(2), 207-239.

Gornick, J. C., \& Heron, A. (2006). The regulation of working time as work-family reconciliation policy: Comparing Europe, Japan, and the United States. Journal of Comparative Policy Analysis Research and Practice, 8(2), 149-166.

Gornick, J. C., \& Jacobs, J. A. (1998). Gender, the welfare state, and public employment: A comparative study of seven industrialized countries. American Sociological Review, $688-710$.
Gottard, A., Mattei, A., \& Vignoli, D. (2015). The relationship between education and fertility in the presence of a time varying frailty component. Journal of the Royal Statistical Society: Series A (Statistics in Society), 178(4), 863-881.

Granrose, C. S., \& Kaplan, E. (1994). Returning to work following childbirth: The relationship between intentions and behavior. Journal of Applied Social Psychology, 24(10), 873-896.

Gustafsson, S., \& Stafford, F. P. (1994). Three regimes of child care: The United States, the Netherlands, and Sweden. Social protection versus economic flexibility: Is there a tradeoff?. University of Chicago Press333-362.

Gutiérrez-Domènech, M. (2008). The impact of the labour market on the timing of marriage and births in Spain. Journal of Population Economics, 21(1), 83-110.

Hazan, M., \& Zoabi, H. (2015). Do highly educated women choose smaller families? The Economic Journal, 125(587), 1191-1226.

Huijts, T., Kraaykamp, G., \& Subramanian, S. V. (2011). Childlessness and psychological well-being in context: A multilevel study on 24 European countries. European Sociological Review, 29(1), 32-47.

Hurrelmann, K. (2003). Der entstrukturierte Lebenslauf. Die Auswirkungen der Expansion der Jugendphase. ZSE: Zeitschrift far Soziologie der Erziehung und Sozialisation, 23(2), $115-126$.

Impicciatore, R., \& Dalla Zuanna, G. (2017). The impact of education on fertility in Italy. Changes across cohorts and south-north differences. Quality \& Quantity, 51(5), 2293-2317.

Inglehart, R. (1997). Modernization and postmodernization: Cultural, economic, and political change in 43 societies, Vol. 19. Princeton, NJ: Princeton University Press.

Inglehart, R. (1971). The silent revolution in Europe: Intergenerational change in postindustrial societies. The American Political Science Review, 65(4), 991-1017.

Janus, A. L. (2013). The implications of family policy regimes for mothers' autonomy. Research in Social Stratification and Mobility, 34, 96-110.

Kalleberg, A. L. (2000). Nonstandard employment relations: Part-time, temporary and contract work. Annual Review of Sociology, 26(1), 341-365.

Kalwij, A. (2010). The impact of family policy expenditure on fertility in western Europe. Demography, 47(2), 503-519.

Karabchuk, T. (2016). The subjective well-being of women in Europe: Children, work and employment protection legislation. Mind \& Society, 15(2), 219-245.

Klesment, M., Puur, A., Rahnu, L., \& Sakkeus, L. (2014). Varying association between education and second births in Europe: Comparative analysis based on the EU-SILC data. Demographic Research, 31, 813-860.

Kolk, M. (2019). Weak support for a U-shaped pattern between societal gender equality and fertility when comparing societies across time. Demographic Research, 40, 27-48.

Koropeckyj-Cox, T., \& Pendell, G. (2007). The gender gap in attitudes about childlessness in the United States. Journal of Marriage and the Family, 69(4), 899-915.

Kravdal, Ø., \& Rindfuss, R. R. (2008). Changing relationships between education and fertility: A study of women and men born 1940 to 1964. American Sociological Review, 73(5), 854-873.

Kreyenfeld, M. (2009). Uncertainties in female employment careers and the postponement of parenthood in Germany. European Sociological Review, 26(3), 351-366.

Laird, J. (2017). Public sector employment inequality in the United States and the great recession. Demography, 54(1), 391-411.

Lalive, R., \& Zweimüller, J. (2009). How does parental leave affect fertility and return to work? Evidence from two natural experiments. The Quarterly Journal of Economics, 124(3), 1363-1402.

Lesthaeghe, R. (1995). In K. O. Mason, \& A.-M. Jensen (Eds.). The second demographic transition in Western countries: An interpretation. Gender and family change in industrialized countries (pp. 17-62). Oxford: Clarendon Press.

Lesthaeghe, R. (2010). The unfolding story of the second demographic transition. Population and Development Review, 36(2), 211-251.

Lesthaeghe, R., \& Surkyn, J. (1988). Cultural dynamics and economic theories of fertility change. Population and Development Review, 1-45.

Lesthaeghe, R., \& Surkyn, J. (2007). When history moves on: The foundations and diffusion of the second demographic transition. International family change. Routledge95-132.

Lichter, D. T., Turner, R. N., \& Sassler, S. (2010). National estimates of the rise in serial cohabitation. Social Science Research, 39(5), 754-765.

Liefbroer, A. C., \& Billari, F. C. (2010). Bringing norms back in: A theoretical and empirical discussion of their importance for understanding demographic behaviour. Population, Space and Place, 16(4), 287-305.

Liefbroer, A. C., \& Corijn, M. (1999). Who, what, where, and when? Specifying the impact of educational attainment and labour force participation on family formation. European Journal of Population, 15(1), 45-75.

Luci-Greulich, A., \& Thévenon, O. (2013). The impact of family policies on fertility trends in developed countries. European Journal of Population/Revue européenne de Démographie, 29(4), 387-416.

Luppi, F. (2016). When is the second one coming? The effect of couple's subjective wellbeing following the onset of parenthood. European Journal of Population, 32(3), 421-444.

Mandel, H., \& Semyonov, M. (2006). A welfare state paradox: State interventions and women's employment opportunities in 22 Countries. The American Journal of Sociology, 111(6), 1910-1949.

Martin Garcia, T., \& Castro-Martin, T. (2013). Do women working in the public sector have it easier to become mothers in Spain? Population Review, 52(1).

Matysiak, A., \& Węziak-Białowolska, D. (2016). Country-specific conditions for work and family reconciliation: An attempt at quantification. European Journal of Population, 32(4), 475-510.

Matysiak, A., Mencarini, L., \& Vignoli, D. (2016). Work-family conflict moderates the relationship between childbearing and subjective well-being. European Journal of Population, 32(3), 355-379.

McDonald, P. (2006). Low fertility and the state: The efficacy of policy. Population and 
Development Review, 32(3), 485-510.

McDonald, P. (2000a). Gender equity in theories of fertility transition. Population and Development Review, 26(3), 427-439.

McDonald, P. (2000b). Gender equity, social institutions and the future of fertility. Journal of the Australian Population Association, 17(1), 1-16.

Merz, E. M., \& Liefbroer, A. C. (2012). The attitude toward voluntary childlessness in Europe: Cultural and institutional explanations. Journal of Marriage and the Family, 74(3), 587-600.

Mills, M., \& Blossfeld, H. P. (2013). The second demographic transition meets globalization: A comprehensive theory to understand changes in family formation in an era of rising uncertainty. In A. Evans, \& J. Baxter (Eds.). Negotiating the life course (pp. 933). Dordrecht: Springer.

Mills, M., Blossfeld, H. P., \& Klijzing, E. (2005). Becoming an adult in uncertain times. Globalization, uncertainty and youth in society: The losers in a globalizing world. London/ New York: Routledge Advances in Sociology Series423-441.

Myrskylä, M., Kohler, H. P., \& Billari, F. C. (2009). Advances in development reverse fertility declines. Nature, 460(7256), 741-743.

Nisén, J., Martikainen, P., Kaprio, J., \& Silventoinen, K. (2013). Educational differences in completed fertility: A behavioural genetic study of Finnish male and female twins. Demography, 50(4), 1399-1420.

Nisén, J., Martikainen, P., Silventoinen, K., \& Myrskylä, M. (2014). Age-specific fertility by educational level in the Finnish male cohort born 1940-50. Demographic Research, 31(1), 119-136.

Nitsche, N., Matysiak, A., Van Bavel, J., \& Vignoli, D. (2018). Partners' educational pairings and fertility across Europe. Demography.

OECD (1999). Employment outlook 1999. Paris: OECD.

Oppenheimer, V. K. (1995). The role of women's economic independence in marriage formation: A Skeptic's response to Annemette Sorensen's remarks. Family formation in modern societies and the new role of women. Boulder: Westview Press236-243.

Palier, B., \& Martin, C. (2007). Editorial introduction from "a frozen landscape"to structural reforms: The sequential transformation of bismarckian welfare systems. Social Policy \& Administration, 41(6), 535-554.

Perelli-Harris, B. (2014). How similar are cohabiting and married parents? Second conception risks by union type in the United States and across Europe. European Journal of Population, 30(4), 437-464.

Perelli-Harris, B., \& Lyons-Amos, M. (2016). Partnership patterns in the United States and across Europe: The role of education and country context. Social Forces, 95(1), 251-282.

Perelli-Harris, B., Sigle-Rushton, W., Kreyenfeld, M., Lappegård, T., Keizer, R., \& Berghammer, C. (2010). The educational gradient of childbearing within cohabitation in Europe. Population and Development Review, 36(4), 775-801.

Pfau-Effinger, B. (2005). Welfare state policies and the development of care arrangements. European Societies, 7(2), 321-347.

Prifti, E., \& Vuri, D. (2013). Employment protection and fertility: Evidence from the 1990 Italian reform. Labour Economics, 23, 77-88.

Ray, R., Gornick, J. C., \& Schmitt, J. (2010). Who cares? Assessing generosity and gender equality in parental leave policy designs in 21 countries. Journal of European Social Policy, 20(3), 196-216.

Rønsen, M., \& Skrede, K. (2010). Can public policies sustain fertility in the Nordic countries? Lessons from the past and questions for the future. Demographic Research, 22(13), 321-346.

Rosenfeld, R. A., Van Buren, M. E., \& Kalleberg, A. L. (1998). Gender differences in supervisory authority: Variation among advanced industrialized democracies. Social Science Research, 27(1), 23-49.

Rovny, A. E. (2011). Welfare state policy determinants of fertility level: A comparative analysis. Journal of European Social Policy, 21(4), 335-347.

Rueda, D. (2005). Insider-outsider politics in industrialized democracies: The challenge to social democratic parties. The American Political Science Review, 99(1), 61-74.

Saraceno, C., \& Keck, W. (2008). The institutional framework of intergenerational family obligations in Europe: A conceptual and methodological overview. Multilinks project, WP1. Berlin: WZB Social Science Research Center.

Schmitt, C. (2012). Labour markets integration, occupational uncertainties, and fertility choices in Germany and the UK. Demographic Research, 26(12), 253-292.

Skrondal, A., \& Rabe-Hesketh, S. (2004). Generalized latent variable modeling: Multilevel, longitudinal, and structural equation models. Boca Raton, FL: Chapman \& Hall/Crc Press.

Snijders, T., \& Bosker, R. (1999). Multilevel analysis: An introduction to basic and applied multilevel analysis. London: Sage.

Sobotka, T. (2008). Overview chapter 6: The diverse faces of the second demographic transition in Europe. Demographic Research, 19(8), 171-224.

Stevenson, B., \& Wolfers, J. (2007). Marriage and divorce: Changes and their driving forces. The Journal of Economic Perspectives, 21(2), 27-52.

Stier, H., \& Yaish, M. (2008). The determinants of women's employment dynamics: The case of Israeli women. European Sociological Review, 24(3), 363-377.

Stier, H., Lewin-Epstein, N., \& Braun, M. (2012). Work-family conflict in comparative perspective: The role of social policies. Research in Social Stratification and Mobility, 30(3), 265-279.

Sullivan, O., Billari, F. C., \& Altintas, E. (2014). Fathers' changing contributions to child care and domestic work in very low-Fertility countries: The effect of education. Journal of Family Issues, 35(8), 1048-1065.

Surkyn, J., \& Lesthaeghe, R. (2004). Value orientations and the second demographic transition (SDT) in Northern, Western and Southern Europe: An update. Demographic Research, 3, 45-86.

Thévenon, O. (2011). Family policies in OECD countries: A comparative analysis. Population and Development Review, 37(1), 57-87.

United Nations (2010). The millennium development goals reportWashington: United Nations.

van de Kaa, D. J. (2001). Postmodern fertility preferences: From changing value orientation to new behavior. Population and Development Review, 27, 290-331.

van de Kaa, D. J. (2002). The idea of a second demographic transition in industrialized countries. Birth, 35, 45 .

Vignoli, D., Drefahl, S., \& De Santis, G. (2012). Whose job instability affects the likelihood of becoming a parent in Italy? A tale of two partners. Demographic Research, 26(I).

Vos, A. E. (2009). Falling fertility rates: New challenges to the European welfare state. Socio-economic Review, 7(3), 485-503.

Walsh, J. (2007). Experiencing part-time work: Temporal tensions, social relations and the work-Family interface. British Journal of Industrial Relations, 45(1), 155-177.

Wolbers, M. H. (2007). Patterns of labour market entry: A comparative perspective on school-to-work transitions in 11 European countries. Acta Sociologica, 50(3), 189-210.

Wood, J., Neels, K., \& Kil, T. (2014). The educational gradient of childlessness and cohort parity progression in 14 low fertility countries. Demographic Research, 31, 1365-1416.

Zaidi, B., \& Morgan, S. P. (2017). The second demographic transition: A review and appraisal. Annual Review of Sociology, 43, 473-492. 